\title{
Impacts of Enhanced Central Pacific ENSO on Wave Climate and Headland-Bay Beach Morphology
}

Thomas R. Mortlock ${ }^{1,2 *}$, Ian D. Goodwin ${ }^{1}$

${ }^{1}$ Marine Climate Risk Group, Department of Environmental Sciences, Macquarie University, North Ryde, NSW 2109, Australia.

${ }^{2}$ Risk Frontiers, Macquarie University, North Ryde, NSW 2109, Australia

* Corresponding author. Postal Address: Room 825, Building E7A, Macquarie University, North Ryde, NSW 2109, Australia. Phone: +61 (0)2 9850 6372, Email: thomas.mortlock@mq.edu.au

\begin{abstract}
Wave climate and Pacific basin coastalbehaviour associated with El Niño Southern Oscillation (ENSO) is understood at a reconnaissance level, but the coastal response to different central Pacific (CP) versus eastern Pacific (EP)flavours of ENSO is unknown. We show that CP ENSO events produce different patterns of directional wave power to EP ENSO along the southeast Australian shelf and southwest Pacific region, because of significant variability in trade-wind wave generation. The modulation of the trade wind wave climate during CP ENSO has thus far been neglected in existing coastal process studies. We also show that coastal change between CP and EP ENSO cannot be inferred from shifts in the deepwater wave climate. This is because variability in trade wind wave generation is masked in deepwater by the persistence of high power extra-tropical waves that have reduced impact on nearshore processes due to high wave refraction. Morphodynamic modelling in a
\end{abstract}


headland-bay beach indicates that CP ENSO leads to higher coastal erosion potential and slower post-storm recovery than EP ENSO during an El Niño/La Niña cycle.We show that the alongshore variability in beach morphological type can be used to model the static equilibrium planform response for each ENSO phase.Results indicate thatshoreline response to ENSO in most headland-bay beach coasts is not as simple as the existing paradigm that (anti-) clockwise rotation occurs during El Niño (La Niña). Our methods provide a secondorder approach to project coastal response and predict the discrete shoreline rotations for ENSO flavours.

\section{KEYWORDS}

ENSO; Wave climate;Headland-bay beach;Coastal processes; Sediment transport 


\section{INTRODUCTION}

There remains considerable uncertainty in the prediction of future shifts in ENSO behaviour from Global Climate Modelling (GCM) because of the non-linearity of ENSO and complex coupled feedbacks (Watanabe et al., 2012). Downscaled projections of regional wave climate inherit this uncertainty and are highly variable, especially for Pacific regions directly impacted by ENSO and on sub-annual timescales (Mori et al., 2013; Hemeret al., 2013). There remains, therefore, a significant knowledge gap in how Pacific coasts will respond to future changes in ENSO.

Multi-decadal wave buoy observations along the south east Australian shelf (SEAS), in the south west Pacific, have shown that ENSO significantly modulateswave climate directionality and intensity (Goodwin, 2005; Harleyet al, 2010). In broad terms, El Niño promotes bi-directional south easterly and easterly wave conditions, while La Niña and ENSO-neutral phases are correlated with a more uni-directional south easterly wave climate. A greater number of storms occur during La Niña (Browning and Goodwin, 2013), in contrast to the eastern Pacific where El Niño is most damaging (Storlazzi and Griggs, 2000).

The latitudinal displacement of the Subtropical Ridge (STR), the latitude of highest pressure over East Australia, also exerts a strong influence on the seasonal wave climate (Mortlock and Goodwin, 2015) and impact of ENSO. ENSO wave climates are also coupled to the Southern Annular Mode (SAM) (Hemer et al., 2009), particularly during Austral winter. The SAM describes the see-saw of atmospheric mass between the mid-latitude westerlies and Antarctica (Marshall, 2003). Positive SAM represents a poleward displacement of the westerlies, and reinforces a La Niña wave climate through the modulation of Southern Ocean and Southern Tasman Sea wave generation. The opposite is true during negative SAM and El Niño wave climate. 
Mortlock and Goodwin (2015) have showed that the directional wave climate along the SEAS can be encapsulated in three primary modes of variability (Figure $1 \mathrm{a}$ ). A sub-tropical easterly mode is modulated by south Pacific trade winds (Mode 1); a south-easterly mode is generated locally in the Tasman Sea (Mode 2) and an extra-tropical southerly mode is related to the strength of the mid-latitude westerlies (Mode 3).

Similar to other Southern Hemisphere coastlines, the south east Australian coast is meridionally oriented with a predominant south to north longshore sediment transport regime (Figure 1 a). Sediment transport cells are divided by prominent headlands, leading to the repetition of headland-bay beach morphology along much of the 1,200 $\mathrm{km}$ of coastline length. Under this configuration, the headland is located to the south, with the parabolic beach adjacent to the north. A Mode 1 wave climate produces cross-onshore wave conditions, Mode 2 onshore, and Mode 3 oblique(Figure $1 \mathrm{~b}$ ). The planform geometry of these coastal sections is well described by the Parabolic Bay Shape Equation (PBSE) developed by Hsu and Evans (1989). Downdrift (north) of the parabola, the planform is oriented normal to the modal wave direction.

Shifts in the orientation of headland-bay beach compartments are linked todirectional variability in the SEAS wave climatewith ENSO (Goodwin et al., 2006; 2013).CollaroyNarrabeen Beach and Palm Beach, two embayed compartments in Sydney, rotate clockwise (anti-clockwise) during biennial El Niño (La Niña) events (Short et al., 2000; Ranasinghe et al., 2004), because of shifts in wave directionality (Ranasinghe et al., 2004; Harley et al., 2015). Recent research suggests that coastline fluctuations observed along this section of coast are part of a synchronous Pacific basin-wide response to ENSO forcing (Barnard et al., 2015). 
While a connection between El Niño/La Niña wave climate and coastal response is established, our current understanding of coastal impacts on Pacific coastlines has not yet accounted for different flavours of ENSO. Most observational studies relate to an eastern Pacific (EP) El Niño or La Niña climate that is characterised by a canonical pattern of surface warming or cooling in the eastern Pacific. However, ENSO anomalies also develop in the central Pacific (CP). CP ENSO events (also known as ENSO Modoki) have become more frequent in recent decades (Lee and McPhaden, 2010) and some GCMs indicate this will continue with greenhouse warming (Yeh et al., 2009). It is therefore important to understand whether the wave climate and coastal response to CP ENSO is significantly different to EP ENSO.

We focus on the modal (non-storm) wave climate as a predictand of the ENSO Pacific climate state and as the principle driver of large-scale coastal behaviour. A moderate wave energy regime exists in the Tasman Sea where modal wave conditions constitute $95 \%$ of all observations (Mortlock and Goodwin, 2015). Our focus on the modal wave climate thus encapsulates the directional wave variability along the SEAS and provides a large sample size for statistical analysis. While storm events are an important driver of coastal stability, modal wave conditions are responsible for shaping the long-term planform geometry. Moreover, there is no robust relationship between storm wave directionality and phases of ENSO in Southeast Australia because of the influence of the SAM on the generation of extreme sub-tropical storms. The directionality of the modal wave climate, however, is well correlated to ENSO (Goodwin, 2005) and thus a more robust predictand of the ENSO Pacific climate state for Southeast Australia.

We use over 20 years of mid-shelf and directional buoy observations to examine shifts in wave power and wave generation with EP and CP ENSO along the south east Australian shelf. We then use a morphodynamic model to investigate whether enhanced CP ENSO 
produces a distinct morphological response at Terrigal-Wamberal $\left(33.4^{\circ} \mathrm{S}, 151.4^{\circ} \mathrm{E}\right)$, a classic parabolic shaped headland-bay beach $60 \mathrm{~km}$ north of Sydney.Shoreline oscillation and rotation at Terrigal-Wamberal (hereafter, 'Wamberal') is synchronous with other embayed compartments in Southeast Australia (Short et al., 2014; Bracs et al., 2016) and thus indicative of the region. Moreover, the shoreline planform at Wamberal is close to the limiting static planform (after Hsu and Evans, 1989), meaning results can be applied to understanding shoreline response to ENSO phases at other static-planform locations.

We also investigate the extent to which the deepwater wave climate is a valid indicator of nearshore change. The alongshore variability insurf-zone morphology is used as an indicator of coastal vulnerability and also as a measure of geometric planform change.An ensemble of coupled ENSO wave climates and beach states are presented for an idealised headland-bay beach configuration, which can be used to model scenarios of coastal impacts as GCM projections of ENSO improve.

\section{METHODOLOGY}

\subsection{Identification of ENSO events}

Austral oceanic summers (January to March, JFM) and winters (July to September, JAS) during eitherEP orCP El Niño/La Niña events were identified over the period of directional buoy observations, fromthe monthly Niño 3.4 index (NINO3.4) and El Niño Modoki Index (EMI)(Figure 2). The definition of CP ENSO in this study is therefore synonymous with ENSO Modoki after Ashok et al. (2007).

Where possible, a suitable coupling with the SAM and allowance for time lags between indices and wave climate response were considered. Selected EP ENSO periods were based 
on those identified by the Oceanic Niño Index (ONI). Selected CP ENSO events were crosschecked with those identified in the literature (e.g. Shinoda et al., 2011). The wave climates of the selected ENSO periods are given in Table 1.

\subsection{Parametric Wave Data}

Directional wave observations from buoys at Sydney (1992 - 2013) and North Stradbroke Island (40 km west of Brisbane, hereafter referred to as 'Brisbane') (1997 - 2013) were used to represent the mid-shelf $(60-80 \mathrm{~m}$ water depth) wave climates of ENSO periodsalong the SEAS (Figure 1 a). Daily-averaged significant wave height, $H_{s}$, peak spectral wave period, $T_{p}$, and mean wave direction, $M W D$, were used.

Since our focus is on the modal (non-storm) wave climate, all storm events were omitted from the buoy records using a Peaks-over-Threshold (PoT) method. The $10 \%$ daily exceedance $H_{s}$ was used with a three-day minimum storm duration at Sydney, after Mortlock and Goodwin (2015) found this to return the best split between ambient and extreme wave distributions. At Brisbane, a second threshold using the 5\% daily exceedance $H_{s}$ with a 1-day minimum duration was also applied in order to filter high energy and transient tropical cyclone storm events from the record.

\subsection{Directional Wave Hindcast}

$M W D$ at Brisbane was hindcast for summer 1996 using cumulative distribution function (CDF) matching (Brocca et al., 2011) of summer wave directions at the Sydney buoy to capture the summer EP La Niña wave climate (Figure 3). Figure $4 \mathrm{~d}$ shows an improved correlation exists between CDF-matched Sydney wave directions and those observed at Brisbane, than between uncorrected Sydney wave directions and observations at Brisbane, over a blind test period (Figure 3 a). 


\subsection{Wave Climate Typology}

The three primary modes of wave climate variability presented in Figure 1 were further decomposed into six synoptic-scale modal 'wave climate types' (WCT) using a combined statistical-synoptic typing method after Mortlock and Goodwin (2015). Figure 4 shows the mean sea level pressure (MSLP) anomaly patterns for each of these WCTs over the Tasman Sea. AllWCTsare identifiable in bothAustral summer and winter, apart from Mode $2 \mathrm{~b}$ which at Sydney only exists as a summer pattern. Modes $3 a$ and $3 b$ are not seen at the Brisbane buoy due to a north-west trending shoreline north of Cape Byron. A detailed discussion of each WCT is provided in Mortlock and Goodwin (2015).Here we use the WCT discretization to relate directional wave power to zonal Pacific circulation.

\subsection{Patterns of ENSO Directional Wave Power}

The total wave power, $P_{W}$, delivered by each wave climate type was used to describe the pattern of directional wave power for each ENSO period. $P_{W}$ is the integral of the wave power density of each daily wave event, $P_{0}$, over the duration of each $\mathrm{WCT}, t$, given in megawatt-hours per metre wave-crest-length $\left(\mathrm{MWh} \mathrm{m}^{-1}\right)$ :

$$
P_{W}=\int_{0}^{t} P_{0} d t
$$

To ensure no bias of $P_{W}$ away from periods with data gaps due to instrumental error, the frequency of occurrence of each WCT was up-scaled from the observed record to simulate $100 \%$ data recovery at the buoys. The frequency of occurrence of each WCT was then detrended before calculating $P_{W}$.

A two-tailed student t-test was used to determine whether the difference between patterns of ENSO directional wave powerwas significant (to $90 \%$ confidence). This was based on the frequency of occurrence of each WCT during each ENSO period (Table 2). 
Significantdifferences between wave power generated by individual WCTs, rather than the wave climate as a whole, were also determined between EP and CP ENSOclimates. If differences exceeded one standard deviation of the interannual wave power variability for the respective WCT, it was considered significant to the $90 \% \mathrm{CI}$.

\subsection{Morphodynamic Modelling of a Headland-Bay Beach}

ENSO wave climates at Sydney were transformed to Wamberal, $60 \mathrm{~km}$ north (Figure 5), to investigatethe morphodynamic response to ENSO ina typical headland-bay beach in Southeast Australia. A coupled MIKE21/3 model of the embayment was nested within a regional MIKE21 Spectral Wave (SW) model. MIKE21/3 dynamically couples a spectral wave, hydrodynamic and sand transport module to simulate bathymetric evolution by wavedriven currents based on Reynolds-averaged Navier-Stokes theory (DHI, 2014).

\subsubsection{Model Configuration}

The model was configured to isolate wave forcing, so no terrestrial sediment inputs, tides, local winds or ambient currents were included. Headland sand bypassing is essentially switched off for this experiment, since the embayed geometry of the regional coast and the incised nature of the Wamberal embayment prevent bypassing during modal wave conditions. A detailed description of the model configurationis provided in Supporting Information (Table S1). High spatial resolution $\left(5 \mathrm{~m}^{2}\right)$ LIDAR bathymetry (March 2008) was used to represent the shoreface to $30 \mathrm{~m}$ depth.

Bathymetric data was smoothed in the model to provide a starting bathymetry representative of a typical embayed beach configuration close to equilibrium. All subaqueous reef around Terrigal Headland was omitted, and only areas of the embayment with a sand bottom were 
modelled (Figure 5). Thus while the study site was based on planform geometry and wave climate at Wamberal, the modelling case was further idealized to be regionally representative.

\subsubsection{Model Validation}

Nearshore model performance was verified against eight months of hourly buoy observations (August 2011 to March 2012) at $12 \mathrm{~m}$ depth inside the Wamberal embayment (location Figure 6). Results showed good model skill for wave power $\left(R^{2} 0.76\right.$, slope 1.1$)$ and direction $\left(R^{2} 0.80\right.$, slope 0.84$)$ during modal wave conditions (Figure 6). We attribute the overprediction of wave period (Figure $6 \mathrm{~b}$ ) to a lack of a local wind forcing during validation, whereby an additionalwind sea would add high frequency energy to the spectrum and reduce the modelled wave period. Since ENSO near-coast wind fields are not considered in this study, we consider the model to perform adequately for wave-only conditions.

No specific morphological validation of the model was undertaken because the study site was modified to represent an idealized regional case.However, the modelled morphological behaviour conforms with observations of wave climate forcing and surf zone response observed at Wamberal from a $\sim 40$ year archive of available photogrammetry and aerial photography. Moreover, other global studies have shown MIKE21/3 to produce a good representation of morphological change on the upper shoreface when compared with observations (Zyserman and Johnson, 2002; Dronen et al., 2012; Kristensen et al., 2013). In addition, results presented here considererror in morphological modelling by the ommision of all bed elevation change within one standard deviation of the mean $(\approx$ zero $)$. The modelled cumulative bed elevation change was normally-distributed for each ENSO case with a mean approximate to zero after outliers were removed.Under a Gaussian distribution, all vertical difference beyond one standard deviation of the mean was considered to be significant to the $90 \%$ CI. 


\subsubsection{Boundary Wave Forcing}

A three-month time series of daily offshore modal wave conditions for each ENSO wave climate was generated for model boundary forcing (Figure 7). The observed time series at the Sydney buoy was first indexed by WCT for each ENSO season. This was done so that each wave day could be represented by the centroid parameters $H_{s}, T_{p}$ and $M W D$ of the WCT to which the observation belonged, rather than the actual observation. This method obtained a clearer signal of morphological response between ENSO types in what is a complex mixed sea-swell environment. Centroid parameters were calculated separately for each ENSO period.

A continuous (gap-free) time series was required for modelling. However, missing wave days existed in the observed (buoy) record due to either instrument error at the buoy or omitted storm events. Missing days were filled by first calculating the number of extra days needed per WCT to maintain the frequency of occurrence of each WCT from the portion of the time series observed at the buoy. Each required wave day was then represented by the respective centroid parameters of the corresponding WCT. A random permutation of the required wave days was performed and then inserted into the locations of data gaps in the time series. This provides a 'nudged random' order of WCTs for data gap periods, as the randomness of the sequencing is already weighted by the number of wave days needed. The sequencing of the wave time series is as important as the wave climate itself, as the morphological model dynamically couples waves, flow and bed elevation change at each time step. A six-month wave climate consisting of two cycles of the respective three-month timeseries was then used to force the model to allow sufficient time for an equilibrium beach state to develop.

\section{RESULTS}




\subsection{Impact of ENSO on Seasonal Wave Climate}

At locations where the winter wave climate is strongly influenced by the SAM (south of Cape Byron), patterns of ENSO wave power are most dissimilar during Austral summer when the STR migrates $\sim 4^{\circ}$ poleward, displacing the SAM (and southerly Mode 3 wave power) influence on the sub-tropics. During winter, the wave climate is dominated by Mode 3 power, masking the influence of ENSO.

This is evident at Sydney, where all ENSO wave climates are dissimilar from each other during summer, but not during winter (Table 2). The exception is between summer EP La Niña and CP La Niña, which are not dissimilar (at the 90\% CI) although there is a significant increase in Mode 1a wave power during La Niña Modoki (Figure 8).

While the SAM does not influence the winter wave climate at Brisbane, an open fetch for Coral Sea and Southwest Pacific tradewind wave generation means easterly Mode 1 power dominates in all ENSO phases during summer (Figure 9). As a result, no ENSO wave climates are dissimilar during summer, whereas almost all types are discrete in winter (Table 2). The exception is between winter EP La Niña and CP El Niño, which are not dissimilar.

\subsection{Impact of Central Pacific ENSO on Directional Wave Power}

CP ENSO produces significantly different patterns of directional wave power from EP ENSO at Sydney and Brisbane (Table 2) primarilybecause of the modulation of Mode 1 wave power between the different flavours of ENSO. At both locations, east to north east wave power is greater during EP El Niño than CP El Niño, and CP La Niña than EP La Niña in Austral summer, while the opposite is true in winter (Figure 8 for Sydney, Figure 9 for Brisbane).

The modulation of Mode 1 wave power represents variability in longer-period southwest Pacific trade-wind wave generation and is associated with the position and strength of the 
sub-tropical Anticyclone (STAC). East to north eastwave power is maximised when the STAC is located to the north east of the North Island of New Zealand (summer EP El Niño/CP La Niña, or winter EP La Niña/CP El Niño), and weakest when in the central Tasman Sea (summer EP La Niña/CP El Niño) or over southeast Australia (winter EP El Niño/CP La Niña).

As a result, prolonged periods of CP La Niña enhance wave climate seasonality over successive summer/winters at Sydney and Brisbane, in comparison with EP La Niña. This is manifest in an anti-clockwise (clockwise) rotation of modal wave power during summer (winter). At Sydney, persistent CP La Niña results in lower total modal wave power for consecutive summer/winters (Figure 8), while at Brisbane there is an increase in total wave power in summer but a decrease the following winter (Figure 9).

\subsection{Nearshore Sensitivity to Shifts in the Deepwater Wave Climate}

While discrete patterns of wave power exist in deep water, changes to the nearshore wave climate are more subtle. The nearshore wave climate was output along the seaward edge of the surf zone (5m contour) in the south, centre and north of the embayment.Figure S1 (S2) in Supporting Information shows nearshore results for summer (winter) ENSO model runs with corresponding deepwater boundary wave climate. Results show the nearshore zone is relatively insensitive to shifts in offshore wave direction due to shoaling processes. On average, a one degree shift in the direction of waves entering the surf zone requires a $\sim 35^{\circ}$ shift offshore. At the northern (most exposed) end of the embayment, only $50 \%$ of total offshore wave power reaches the surf zone, while in the headland shadow zone this is reduced to $11 \%$ after refraction.

Both wave power and directional sensitivity vary considerably in the south and centre of the embayment with wave obliquity. When the deepwater mean wave direction is clockwise of 
shore-normal (which is south-east at this location), a $\sim 55^{\circ}$ shift offshore is required for a one degree change in wave direction in the centre/south of the embayment, and only $\sim 15 \%$ of the total deepwater wave power reaches the surf zone. In contrast, when the deepwater wave direction is anti-clockwise of shore-normal, only a $\sim 30^{\circ}$ shift is required for a one degree change in the nearshore wave direction, and twice the amount $(\sim 30 \%)$ of total deepwater wave power reaches the surf zone. The nearshoregeometry is therefore more sensitive to small changes in east and north east waves (modal trade-wind and tropical-origin storm waves)than southerly waves(extra-tropical origin modal and storm waves), despite the latter having much greater total power in deepwater.

This indicates that ENSO-related coastal impacts cannot be directly inferred from the deepwater wave climate because the importance of east and north-easterly waves in the nearshore is masked in deepwater by the persistence of oblique southerly wave conditions which are highly dissipated upon reaching the nearshore. This can be illustrated by comparing the centroid $P_{W}$ values of Mode 1a-type waves (north-easterly trade winds) and Mode 3b-type waves (southerly Southern Tasman Lows) in deepwater (Figure 4). Mode 1a waves produce a mid-shelf, mean annual $P_{W}$ of $8.5 \mathrm{~kW} / \mathrm{m}$, while Mode $3 \mathrm{~b}$ waves produce $17 \mathrm{~kW} / \mathrm{m}$, twice the magnitude of Mode 1a. However,after refraction into the nearshoreboth wave climate types exert comparable amounts of energy on the surf zone. Mode 1a waves retain $\sim 30 \%$ of deepwater power $(\sim 2.6 \mathrm{~kW} / \mathrm{m})$ while Mode $3 \mathrm{~b}$ retain $\sim 15 \%(\sim 2.6 \mathrm{~kW} / \mathrm{m})$.

\subsection{Beach Morphological Response to ENSO}

Figure 10 shows how the surf zone morphology in a headland-bay beach may equilibrate according to the persistence of different ENSO climate states.Morphologies can be divided into two mean states; those produced under north east to south east ENSO wave climates (typical of summer), and those with a significant southerly wave component (typical of 
winter). The differences between morphologies can be viewed in terms of the alongshore variation in the Wright and Short (1984) beach state classification.

Northeast to southeast ENSO wave climates (summer EP El Niño, EP La Niña and CP La Niña and winter EP La Niña)produce a shore-normal, more energetic nearshore wave climate and rhythmic bar and beach (RBB) morphology along the majority of the planform. In the headland shadow zone sand is transferred from the beach toe to a low tide terrace (LTT) with a rip channel separating adjacent morphology to the north. To the east, negligible wave energy produces a reflective beach state with deeper water directly off the toe. The transfer of sand to the LTT is greatest during east to north east wave conditions and may contribute to an apparent anti-clockwise rotation of the shoreline, as proposed by Ranasinghe et al. (2004) at Collaroy-Narrabeen, $30 \mathrm{~km}$ south of Wamberal. If this is the mechanism for rotation at the southern end of the embayment, the sand is only moved a few metres below the water line.

In contrast, southerly ENSO wave climates (winter EP El Niño, CP El Niño and CP La Niña and summer CP El Niño) produce a steep alongshore gradient in nearshore wave power and a reduced-energy wave environment in the south and centre of the embayment, despite having the highest cumulative power offshore. This leads to a transverse bar and rip (TBR) morphology for most of the planform, grading to RBB at the (most exposed) northern end. Less sand is transferred to a LTT in the headland shadow zone during oblique wave conditions.

Only CP El Niño summer and EP La Niña winter lead to seasonal changes in the beach state,despite all summer wave climates being discrete in deep water. CP El Niño summer contains a reduced easterly component producing a more winter-like beach statethan other ENSO summers. EP La Niña winter is a bi-directional north east and south east wave climate (Figure 8) producing a more summer-like beach state than other ENSO winters. 
The starting bathymetry used in the model was captured two weeks after a cluster of small (one year return period) southerly storms. In all cases, an initial period of rapid $( \pm 0.4 \mathrm{~m} /$ day) shoreface recovery was observed in the model lasting eight to ten weeks (from end of storm) before the rate of change significantly slowed and the morphology attained an equilibrium with ambient wave conditions. Modelled shoreface recovery was most rapid when the modal wave direction was close to the antecedent storm direction.

\section{IMPLICATIONS}

Results represent inter-annual ENSO wave climates coupled to variability in the SAM in the extra-tropics. A view of ENSO impact is also presented under a specific large-scale regime in terms of the STR, which is poleward of its mean position for the last 1,000 years (Goodwin et al., 2014). While both these scenarios are anomalous in the long-term, they are relevant for projections for the coming century as greenhouse warming is likely to force a continued expansion of the tropics (Seidel, 2008; Allen et al., 2014) and maintain a strong coupling between SAM and ENSO (Thompson and Wallace, 2000; Wang and Cai, 2013), enhanced by a continued trend towards positive SAM with ozone healing (Mayewski et al., 2015).

\subsection{Coastal Vulnerability with Future ENSO Behaviour}

Despite recent improvements in GCM modelling, there is still no consensus on how ENSO will change with greenhouse warming (Cai et al., 2015b), and regionally downscaled projections inherit this uncertainty. This affords little confidence in assessing future ENSOrelated impacts. Therefore, a scenarios-based approach is required to account for this uncertainty. Results can be used with GCM-based projections of ENSO to model coastal impacts. 
One scenario is an increase in ENSO amplitude, with more frequent extreme El Niño events (that influence the Austral summer wave climate) followed by extreme La Niña events (impacting the following winter and summer wave climates) (Cai et al., 2015a). There is no robust projection of whether an EP or CP pattern is more likely, although extreme La Niña tends to be a central Pacific phenomenon and CP ENSO events have become more frequent in recent decades (Lee and McPhaden, 2010). The coastal impact of both EP and CP ENSO sequences can be idealised based on the coupled wave climate and beach states presented in this study (Figure 11). The alongshore variability in surf-zone morphology can be used as a measure of coastal vulnerability.

For an EP pattern, a longshore bar forms along most of the planform during the first El Niño summer, with greater bar building at the northern end because of an east and south easterly wave climate (Figure 11 a). During the subsequent La Niña winter, a rhythmic bar also forms with greater bar-building in the south/centre of the embayment than during the preceding El Niño phase because of a north easterly wave component (Figure $11 \mathrm{~b}$ ). The second (La Niña) summer wave climate is more uni-directional south easterly, leading to a longshore bar in the centre/north of the embayment, and a transverse bar and rip cell pattern in the southerly third (Figure $11 \mathrm{c}$ ).

For a $\mathrm{CP}$ pattern, the first El Niño summer is characterised by the persistence of transverse bar and rip in the south/centre of the embayment due to (unseasonal) south south easterly wave power with a sub-dominant easterly component (Figure $11 \mathrm{~d}$ ). The following La Niña winter is also south south easterly, but the absence of an easterly component extends the barand-rip morphology of the preceding summer across the whole planform (Figure 11 e). A longshore bar eventually forms during the second (La Niña) summer under a north-easterly wave climate (Figure $11 \mathrm{f}$ ). 
The absence of a continuous bar during the first summer to winter affords less storm wave dissipation during CP ENSO. Moreover, the rip cells focus wave energy and correspond to erosion hotspots. South-easterly storms occur more often during winter and La Niña phases in south east Australia (Browning and Goodwin, 2013). Therefore, the embayment is most vulnerable to storm damage during CP La Niña winter, especially if the preceding summer is a CP El Niño pattern. By comparison, the EP ENSO wave climates provide better storm protection for the sub-aerial beach.

Shoreface recovery from storm cut is most rapid when subsequent modal wave direction is similar to the antecedent storm direction. Therefore, the CP ENSO sequence may lead to slower rates of recovery after La Niña winter storms, because the modal wave climate of the following summer is low power and from the north east while storms are south easterly. In contrast, EP La Niña summer is higher power south easterly and better placed to return sand to the surf zone.

\subsection{Modelling Planform Geometrywith Long-Term Shifts in ENSO}

Shoreline planform geometry is a direct expression of the alongshore variation in surf zone morphology, and is a dominant feature of the classification of Wright and Short (1984). Numerous observational studies (Thornton et al., 2007; Quartel, 2009; Price and Ruessink, 2013) have confirmed that surf zone variability is synchronous with shoreline change. Despite this, models have traditionally treated surf zone morphology and the shoreline separately (van de Lageweg et al., 2013). Recent improvements in shoreline modelling have begun to couple the two-dimensional surf-zone morphology to a one-line expression of the shoreline (e.g. Kaergaard and Fredsoe, 2013), although their application to areas with very high planform curvature such as in the lee of headlands is uncertain. Instead, the Parabolic 
Bay Shape Equation (PBSE) (after Hsu and Evans, 1989) has been shown to provide a good representation of the Static Equilibrium Planform (SEP) of headland-attached bay beaches.

However, a major source of uncertainty in applying the PBSE has always been locating the downcoast end of the parabola, or downcoast 'control point' (Lausman et al., 2010). We suggest that the alongshore variability in the surf zone morphological type of Wright and Short (1984) can be used to locate the downcoast control point needed to model a headland bay-beach shoreline in static equilibrium. We propose that the change from either Low Tide Terrace (LTT) or Transverse Bar and Rip (TBR) to Rhythmic Bar and Beach (RBB)morphology represents the point at which the planform ceases to follows a parabola to where it aligns normal to the wave orthogonal as an equilibrium shoreline response to the persistence of each ENSO wave climate (Figure 12).By locating this point the angle of wave obliquity, $\beta$, and the control line length, $R_{\beta}$, can be found, from which the PBSE can be solved. Here we express $R_{\beta}$ in terms of the compartment length, $L$ for the method to be expanded to other compartments in south east Australia.

Our method reduces computationally intense, two-dimensional morphodynamic modelling of the embayment to a one-line expression of the shoreline for each ENSO climate. It also allows the complexity of bi-modal wave conditions (and thus more than one diffraction point) to be incorporated into the equilibrium planform for each ENSO type, which has also been a difficulty when applying the PBSE to real-world wave conditions.

While headland sand bypassing is essentially switched off in this experiment (Section 2.6.1), the control line and downdrift control point also represents the bypass strand and reattachment point, respectively, for the cross-embayment transport of sand where it occurs. This pathway forms the connector between sand transported in the outer surf zone and the 
down-coast, littoral transport when sand bypasses the headland from an updrift compartment (Goodwin et al., 2013).

Our results can be used toconceptualise Static Equilibrium Planforms that are representative of the long-term persistence of each ENSO wave climate. An EP El Niño summer wave climate confines the parabolic shoreline to the first quarter of the planform (Figure $11 \mathrm{a}$ ). This leads to an anti-clockwise rotation of the shoreline in the lee of the headland, while the rest of the planform is flattened under predominantly shore-normal wave conditions. EP La Niña winter-type conditions lead to a similar pattern (Figure $11 \mathrm{~b}$ ), while the persistence of an EP La Niña summer-type wave climate produces a clockwise rotation at both ends of the embayment (Figure $11 \mathrm{c}$ ).

In comparison, CP El Niño summer and in particular La Niña winter wave conditions lead to a substantial clockwise rotation in the planform (Figure $11 \mathrm{~d}$ and e). In CP La Niña winter, the parabolic shoreline describes almost $70 \%$ of the embayment length. The CP El Niño summer response is geometrically similar to EP La Niña winter. Conversely, CP La Niña summer wave climate produces an anti-clockwise rotation of the planform(Figure $11 \mathrm{f}$ ) that is geometrically similar to EP El Niño summer.

Therefore, the shoreline response to ENSO wave forcing in an embayed beach is more complex than the simple paradigmthat (anti-) clockwise rotation occurs during El Niño (La Niña) for an idealised bathymetry. The existing paradigm has struggled to fully describe the process of shoreline change with ENSO phases, first attributing it exclusively to alongshore (Ranasinghe et al., 2004) and then cross-shore (Harley et al., 2011; 2015) processes.The complex geometric response isa result of real-world shoaling processes, bi-modal wave conditions and the emergence of different flavours of ENSO climate variability.The stratification of the discrete surf zone and shoreline behaviour to each ENSO flavour enables 
a new paradigm for the observed rotation process through the longshore migration of surf zone morphological types with rotating nearshore wave direction.

\section{SUMMARY}

While a link between ENSO, wave climate and coastal behaviour is understood at a reconnaissance level, uncertainties remain as to the coastal responses of CP versus EP ENSO. Using over 20 years of directional and mid-shelf buoy observations, we show that CP ENSO produces significantly different patterns of directional wave power to EP ENSO along the south east Australian shelf, in the south west Pacific, and differences are primarily due to the modulation of easterly, trade-wind generated wave power. The strength of trade-wind wave power is related to the position of the sub-tropical anticyclone which varies between $\mathrm{CP}$ and EP ENSO events.

Changes to the nearshore wave climate and coastal morphologyare more subtle. Using a wave and morphodynamic model, we show that only CP El Niño summers and EP La Niña winters lead to seasonal changes in the surf zone morphology of a headland-bay beach. The nearshore is more sensitive to changes in east and north-east (modal trade-wind and tropical-origin storm) waves than oblique (extra-tropical origin) wave conditions. In deep water, the importance ofthe trade wind wave climate is masked by the persistence of high power extratropical wave conditions that have a reduced impact on nearshore processes due to high refraction. As a result, ENSO-related coastal impacts cannot be directly inferred from shifts in offshore wave direction as previously assumed.

The alongshore variability in surf-zone morphology produced by each ENSO climate state can be used as a measure of coastal vulnerability. During an Austral summer-to-summer El 
Niño/La Niña cycle, a CP ENSO pattern leads to potentially higher storm erosion and slower post-storm recovery than EP ENSO. This is because CP ENSO wave climate is unseasonably oblique before and during the shore-normal La Niña winter storm season. This leads to a bar and rip cell morphology that affords less wave energy dissipation and more energy focussing than during EP ENSO. The following La Niña summer wave climate is significantly more north easterly and low power during CP ENSO than EP ENSO, and slower to return sand to the surf zone.

In addition, we propose that the alongshore variability in the Wright and Short (1984) beach morphological type can be used to locate the cross-embayment bypass strand and thus construct static equilibrium planforms for each ENSO phase. This method can be used to resolve two major uncertainties related to the application of the Parabolic Bay Shape Equation; (i) the location of the downcoast control point and; (ii) the incorporation of realworld wave conditions.Results indicate thatthe shoreline response to ENSO wave forcing in an embayed beach is not as simple as (anti-) clockwise rotation during El Niño (La Niña) as previously suggested, because of shoaling processes, bi-modal wave conditions and the emergence of different flavours of ENSO.

We conclude that on open ocean coastlines in the north and south east Pacific exposed to long-fetch wave climates, the response of coastal geometry to ENSO wave climate flavours may be amplified when compared to our findings for the fetch limited Tasman Sea.

\section{ACKNOWLEDGMENTS}

The Sydney buoy is funded by Office of Environment and Heritage (OEH) NSW and operated by Manly Hydraulics Laboratory. Data is available from 
https://www.mhl.nsw.gov.au/DataRequest.The Brisbane buoy is funded by State of Queensland, Department of Science, Information Technology, Innovation and the Arts. Data is available at https://data.qld.gov.au/dataset/coastal-data-system-waves-brisbane.The Wamberal buoy deployment was funded by Australian Research Council (ARC) Linkage Project (LP100200348), and data is available from the authors. Bathymetries were supplied by OEH NSW and are available on request. T. Mortlock is funded by an International Macquarie University Research Excellence Scholarship in association with ARC LP100200348. The NINO3.4 indexwas sourced from NOAA Climate Prediction Center; the EMI from the Japan Agency for Marine-Earth Science and Technology; the SAM index from National Environment Research Council, UK. An Educational MIKE by DHI Software License was used. Thanks to Will Hibberd at DHI Gold Coast for technical support. We also thank the anonymous reviewers of this paper whose comments significantly improved the work.

\section{REFERENCES}

Allen, R. J., J. R. Norris and M. Kovilakam (2014), Influence of anthropogenic aerosols and the Pacific Decadal Oscillation on tropical belt width. Nature Geoscience 7(4): 270-274. doi: 10.1038/ngeo2091.

Ashok, K., S. K. Behera, S. A. Rao, H. Y. Weng and T. Yamagata (2007), El Nino Modoki and its possible teleconnection. Journal of Geophysical Research-Oceans 112(C11), doi: 10.1029/2006JC003798.

Barnard, P. L., A. D. Short, M. D. Harley, K. D. Splinter, S. Vitousek, I. L. Turner, J. Allan, M. Banno, K. R. Bryan, A. Doria, J. E. Hansen, S. Kato, Y. Kuriyama, E. Randall-Goodwin, 
P. Ruggiero, I. J. Walker and D. K. Heathfield (2015), Coastal vulnerability across the Pacific dominated by El Niño/Southern Oscillation. Nature Geoscience, 8, 801-807. doi: $10.1038 /$ ngeo 2539 .

Bracs, M. (2016), Monitoring sandy shoreline variability on a regional scale: implications for the establishment of a national coastal observing network. Unpublished $\mathrm{PhD}$ thesis, School of Civil and Environmental Engineering, University of New South Wales Australia.

Brocca, L., S. Hasenauer, T. Lacava, F. Melone, T. Moramarco, W. Wagner, W. Dorigo, P. Matgen, J. Martínez-Fernández, P. Llorens, J. Latron, C. Martin and M. Bittelli (2011), Soil moisture estimation through ASCAT and AMSR-E sensors: An intercomparison and validation study across Europe. Remote Sensing of Environment 115(12): 3390-3408, doi:10.1016/j.rse.2011.08.003.

Browning, S. A. and I. D. Goodwin (2013), Large-Scale Influences on the Evolution of Winter Subtropical Maritime Cyclones Affecting Australia's East Coast. Monthly Weather Review 141(7): 2416-2431, doi: 10.1175/mwr-d-12-00312.1.

Cai, W., G. Wang, A. Santoso, M. J. McPhaden, L. Wu, F.-F. Jin, A. Timmermann, M. Collins, G. Vecchi, M. Lengaigne, M. H. England, D. Dommenget, K. Takahashi and E. Guilyardi (2015a), Increased frequency of extreme La Niña events under greenhouse warming. Nature Climate Change 5(2): 132-137, doi: 10.1038/nclimate2492.

Cai, W., A. Santoso, G. Wang, S.-W. Yeh, S.-I. An, K. M. Cobb, M. Collins, E. Guilyardi, F.-F. Jin, J.-S. Kug, M. Lengaigne, M. J. McPhaden, K. Takahashi, A. Timmermann, G. Vecchi, M. Watanabe and L. Wu (2015b), ENSO and greenhouse warming. Nature Climate Change 5(9): 849-859, doi: 10.1038/nclimate2743. 
Dee, D. P., S. M. Uppala, A. J. Simmons, P. Berrisford, P. Poli, S. Kobayashi, U. Andrae, M. A. Balmaseda, G. Balsamo, P. Bauer, P. Bechtold, A. C. M. Beljaars, L. van de Berg, J. Bidlot, N. Bormann, C. Delsol, R. Dragani, M. Fuentes, A. J. Geer, L. Haimberger, S. B. Healy, H. Hersbach, E. V. Hólm, L. Isaksen, P. Kållberg, M. Köhler, M. Matricardi, A. P. McNally, B. M. Monge-Sanz, J. J. Morcrette, B. K. Park, C. Peubey, P. de Rosnay, C. Tavolato, J. N. Thépaut and F. Vitart (2011), The ERA-Interim reanalysis: configuration and performance of the data assimilation system. Quarterly Journal of the Royal Meteorological Society 137(656): 553-597,doi: 10.1002/qj.828.

DHI (2014), MIKE21/3 Coupled Model FM User Guide, MIKE by DHI, Danish Hydraulics Institute, Denmark, $52 \mathrm{pp}$.

Drønen, N., S. Kristensen, M. Taaning, B. Elfrink, and R. Deigaard (2011), Long Term Modeling of Shoreline Response to Coastal Structures, In: Rosati, J.D., P. Wang and T.M. Roberts (ed.), Proceedings of the Coastal Sediments 2011. World Scientific, pp. 965-978.

Goodwin, I. D. (2005), A mid-shelf, mean wave direction climatology for southeastern Australia, and its relationship to the El Niño-Southern Oscillation since 1878A.D. International Journal of Climatology 25(13): 1715-1729, doi: 10.1002/joc.1207.

Goodwin, I. D., M. A. Stables and J. M. Olley (2006), Wave climate, sand budget and shoreline alignment evolution of the Iluka-Woody Bay sand barrier, northern New South Wales, Australia, since 3000 yr BP. Marine Geology 226(1-2): 127-144.doi: 10.1016/j.margeo.2005.09.013.

Goodwin, I. D., R. Freeman and K. Blackmore (2013), An insight into headland sand bypassing and wave climate variability from shoreface bathymetric change at Byron Bay, 
New South Wales, Australia. Marine Geology 341: 29-45. doi: 10.1016/j.margeo.2013.05.005.

Goodwin, I., S. Browning, A. Lorrey, P. Mayewski, S. Phipps, N. N. Bertler, R. Edwards, T. Cohen, T. van Ommen, M. Curran, C. Barr and J. C. Stager (2014), A reconstruction of extratropical Indo-Pacific sea-level pressure patterns during the Medieval Climate Anomaly. Climate Dynamics 43(5-6): 1197-1219. doi: 10.1007/s00382-013-1899-1.

Harley, M. D., I. L. Turner, A. D. Short and R. Ranasinghe (2010), Interannual variability and controls of the Sydney wave climate. International Journal of Climatology 30: 13321335. doi: 10.1002/joc.1962.

Harley, M. D., I. L. Turner, and A. D. Short (2015), New insights into embayed beach rotation: the importance of wave exposure and cross-shore processes. Journal of Geophysical Research: Earth Surface .doi: 10.1002/2014JF003390

Hemer, M. A., J. A. Church and J. R. Hunter (2009), Variability and trends in the directional wave climate of the Southern Hemisphere. International Journal of Climatology 30: 475-491. doi: 10.1002/joc. 1900 .

Hemer, M. A., Y. Fan, N. Mori, A. Semedo and X. L. Wang (2013), Projected changes in wave climate from a multi-model ensemble. Nature Climate Change 3(5): 471-476, doi:10.1038/nclimate1791.

Hsu, J.R.C., and C. Evans (1989), Parabolic bay shapes and applications. Proceedings of the Institute of Civil Engineers, 87 (2). Thomas Telford, London, pp. 557-570. doi: 10.1680/iicep.1989.3778.

Kaergaard, K. and J. Fredsoe (2013), A numerical shoreline model for shorelines with large curvature. Coastal Engineering 74: 19-32, doi: 10.1016/j.coastaleng.2012.11.011. 
Kristensen, S.E., N. Drønen, R. Deigaarb, and J. Fredsoe (2013), Hybrid morphological modelling of shoreline response to a detached breakwater. Coastal Engineering 71: 13-27, doi: 10.1016/j.coastaleng.2012.06.005.

Lausman, R., A. H. F. Klein and M. J. F. Stive (2010), Uncertainty in the application of the Parabolic Bay Shape Equation: Part 1. Coastal Engineering 57(2): 132-141. doi: 10.1016/j.coastaleng.2009.09.009.

Lee, T. and M. J. McPhaden (2010), Increasing intensity of El Niño in the central-equatorial Pacific. Geophysical Research Letters 37(14). doi: 10.1029/2010GL044007.

Marshall, G. J. (2003), Trends in the southern annular mode from observations and reanalyses. Journal of Climate 16(24): 4134-4143, doi: 10.1175/15200442(2003)016<4134:TITSAM>2.0.CO;2.

Mayewski, P. A., T. Bracegirdle, I. Goodwin, D. Schneider, N. A. N. Bertler, S. Birkel, A. Carleton, M. H. England, J. H. Kang, A. Khan, J. Russell, J. Turner and I. Velicogna (2015), Potential for Southern Hemisphere climate surprises. Journal of Quaternary Science 30(5): 391-395. doi: 10.1002/jqs.2794.

Mori, N., T. Shimura, T. Yasuda and H. Mase (2013), Multi-model climate projections of ocean surface variables under different climate scenarios-Future change of waves, sea level and wind. Ocean Engineering 71: 122-129. doi: 10.1016/j.oceaneng.2013.02.016.

Mortlock, T. R., I. D. Goodwin (2015), Directional wave climate and power variability along the Southeast Australian shelf. Continental Shelf Research 98: 36-53, doi:10.1016/j.csr.2015.02.007. 
Price, T.D. and B.G. Ruessink (2013), Observations and conceptual modelling of morphological coupling in a double sandbar system. Earth Surface Processes and Landforms 38: 477-489, doi: 10.1002/esp.3293.

Quartel, S. (2009), Temporal and spatial behaviour of rip channels in a multiple-barred coastal system. Earth Surface Processes and Landforms 34: 163-176, doi: 10.1002/esp.1685.

Ranasinghe, R., R. McLoughlin, A. Short and G. Symonds (2004), The Southern Oscillation Index, wave climate, and beach rotation. Marine Geology 204(3-4): 273-287, doi:10.1016/S0025-3227(04)00002-7.

Seidel, D. J., Q. Fu, W. J. Randel and T. J. Reichler (2008), Widening of the tropical belt in a changing climate. Nature Geoscience 1(1): 21-24. doi: 10.1038/ngeo.2007.38.

Shinoda, T., H. E. Hurlburt and E. J. Metzger (2011), Anomalous tropical ocean circulation associated with La Niña Modoki. Journal of Geophysical Research 116(C12), doi: 10.1029/2011JC007304.

Short, A.D., Trembanis, A.C., Turner, I., (2000), Beach oscillation, rotation and the Southern Oscillation, Narrabeen Beach, Australia. In: Edge, B.L. (ed.), Proceedings 27th International Coastal Engineering Conference. ASCE, Sydney, pp. 2439-2452.

Short, A., M. Bracs and I. L. Turner (2014), Beach oscillation and rotation: local and regional response on three beaches in southeast Australia. In: Green, A.N. and Cooper, J.A.G. (eds.), Proceedings 13th International Coastal Symposium (Durban, South Africa), Journal of Coastal Research, Special Issue 66, pp. 712-717, doi: 10.2112/SI-120.1.

Storlazzi, C.D. and G.B. Griggs, (2000), Influence of El Niño-Southern Oscillation (ENSO) events on the evolution of central California's shoreline. Geological Society of America Bulletin,112 (2), 236-249. doi: 10.1130/0016-7606(2000)112<236:IOENOE>2.0.CO;2. 
Thompson, D. W. J. and Wallace, J.M. (2000), Annular Modes in the Extratropical Circulation. Part I: Month-to-Month Variability.Journal of Climate, 13: 1000-1016. doi: 10.1175/1520-0442(2000)013<1000:AMITEC>2.0.CO;2.

Thornton, E.B., J. MacMahan and A.H. Sallenger (2007), Rip currents, mega-cusps, and eroding dunes. Marine Geology 240: 151-167, doi: 10.1016/j.margeo.2007.02.018.

van de Lageweg, W.I., K.R. Bryan, G.Coco and B.G. Ruessink (2013), Observations of shoreline-sandbar coupling on an embayed beach. Marine Geology 344: 101-114, doi: 10.1016/j.margeo.2013.07.018.

Watanabe, M., J.-S. Kug, F.-F. Jin, M. Collins, M. Ohba and A. T. Wittenberg (2012), Uncertainty in the ENSO amplitude change from the past to the future. Geophysical Research Letters 39(20). doi: 10.1029/2012g1053305.

Wright, L.D. and Short, A.D. (1984), Morphodynamic Variability of Surf Zones and Beaches: A Synthesis. Marine Geology, 56(1-4): 93-118. doi:10.1016/0025-3227(84)900082.

Yeh, S. W., J. S. Kug, B. Dewitte, M. H. Kwon, B. P. Kirtman and F. F. Jin (2009), El Nino in a changing climate. Nature 461(7263): 511-514, doi: 10.1038/nature08316.

Zyserman, J.A. and H.K. Johnson (2002), Modelling morphological processes in the vicinity of shore-parallel breakwaters. Coastal Engineering, 45(3-4): 261-284, doi: 10.1016/S0378$3839(02) 00037-6$. 


\section{TABLES}

Table 1. Three month periods used to represent ENSO wave climates from the available buoy record (1992-2013).

\begin{tabular}{lcc}
\hline & Austral Summer & Austral Winter \\
\hline EP El Niño & JFM 1998 & JAS 1997 \\
CP El Niño & JFM 2010 & JAS 2002 \\
EP La Niña & JFM 1996 & JAS 1998 \\
CP La Niña & JFM 2009 & JAS 2010 \\
\hline
\end{tabular}

Table 2.Dissimilarity matrix of Austral summer (winter) ENSO wave climates using a twotailed student t-test. $0(1)=$ distributions are $(n o t)$ dissimilar between ENSO types $(90 \% \mathrm{CI})$.

\begin{tabular}{|c|c|c|c|c|}
\hline & EP El Niño & CP El Niño & EP La Niña & CP La Niña \\
\hline \multicolumn{5}{|l|}{ a) Sydney } \\
\hline EP El Niño & $\mathrm{n} / \mathrm{a}$ & $0(1)$ & $0(1)$ & $0(1)$ \\
\hline CP El Niño & $0(1)$ & $\mathrm{n} / \mathrm{a}$ & $0(1)$ & $0(1)$ \\
\hline EP La Niña & $0(1)$ & $0(1)$ & $\mathrm{n} / \mathrm{a}$ & $1(1)$ \\
\hline CP La Niña & $0(1)$ & $0(1)$ & $1(1)$ & $\mathrm{n} / \mathrm{a}$ \\
\hline \multicolumn{5}{|l|}{ b) Brisbane } \\
\hline EP El Niño & $\mathrm{n} / \mathrm{a}$ & $1(0)$ & $1(0)$ & $1(0)$ \\
\hline CP El Niño & $1(0)$ & $\mathrm{n} / \mathrm{a}$ & $1(1)$ & $1(0)$ \\
\hline EP La Niña & $1(0)$ & $1(1)$ & $\mathrm{n} / \mathrm{a}$ & $1(0)$ \\
\hline CP La Niña & $1(0)$ & $1(0)$ & $1(0)$ & $\mathrm{n} / \mathrm{a}$ \\
\hline
\end{tabular}




\section{FIGURE CAPTIONS}

Figure 1a) Three primary modes of wave climate variability in the Tasman Sea with locations of Sydney, Brisbane and Terrigal-Wamberal wave buoys. Inset shows relation to south Pacific and Southern Ocean; b) conceptualisation of planform rotation in a headlandbay beach in south east Australia.

Figure 2Monthly values of the EMI (red line), NINO3.4 (black line) and three-month running mean of the monthly SAM index (grey shade) over the period of directional buoy operation. The sign of the SAM has been inverted for visualization of coupling with NINO3.4. Y-axis shows Sea Surface Temperature (SST) anomaly (in the case of the EMI and NINO3.4) and zonal mean SLP difference between $40^{\circ}$ and $60^{\circ} \mathrm{S}$ (in the case of the SAM). Selected Austral oceanic summer (JFM) and winter (JAS) periods for EP El Niño (E.EN, blue), EP La Niña (E.LN, orange), CP El Niño (C.EN, purple) and CP La Niña (C.LN, green) are shown.

Figure 3 Cumulative Distribution Function (CDF) matching of Sydney summer MWD with Brisbane showing (a) scatter plot of Brisbane and Sydney daily summer MWD (1997 - 2012) used as model training dataset, with quantiles (blue) and linear regression (red line), (b) CDF of MWD observed at Brisbane (grey), observed at Sydney (blue), and CDF-matched for Brisbane (red), (c) the same for PDF of $M W D$, and (d) scatter plot with quantiles of Brisbane MWD observed (obs.) and modelled (mod.) for a blind test (using JFM 2013).

Figure 4 Composite anomalies $(\mathrm{hPa})$ of mean sea level pressure using ERA-Interim Reanalysis 1979-2013 (Dee et al., 2011) for synoptic-scale wave climate types in the Tasman Sea. Arrows are indicative of mean wave direction at the Sydney buoy. 
Figure 5 Location of Terrigal-Wamberal with upper and lower shoreface (15m isobar) and lower shoreface and inner shelf breaks (30m isobar). Extent of morphodynamic model (black rectangle) and nearshore buoy are shown. Inset shows extent of regional wave model and Sydney buoy.

Figure 6 Validation of spectral wave model for (a) wave height, (b) period, (c) direction and (d) power (y-axis) against hourly buoy measurements (x-axis) for modal (non-storm) wave conditions. Quantiles are shown in blue, linear trends in red. Model parameter $H_{m 01}$ was compared to buoy parameter $H_{s}$ in (a), and $T_{m 01}$ vs. $T_{z}$ in (b).

Figure 7Time series of daily modal waves for each ENSO wave climate at the Sydney buoy. $\mathrm{X}$-axis shows number of days (summers $=90$ days, winters $=92$ days), $\mathrm{y}$-axis shows wave climate type (WCT). Red dots indicate location of missing wave days.

Figure 8 Directional (mid-shelf) wave power, $P_{W}\left(\mathrm{MWh} \mathrm{m}^{-1}\right)$, discretised by wave climate type during summer and winter EP El Niño (E.EN), EP La Niña (E.LN), CP El Niño (C.EN) and CP La Niña (C. LN) events at Sydney. Anomalous $P_{W}$ between EP and CP ENSO is shown with significant anomalies in red. Total $P_{W}$ for each ENSO period $\left(\Sigma P_{W}\right)$ and the difference between EP and CP ENSO $\left(\Delta \Sigma P_{W}\right)$ is also shown.

Figure 9 Directional (mid-shelf) wave power, $P_{W}\left(\mathrm{MWh} \mathrm{m}^{-1}\right)$, at Brisbane discretised by wave climate type.

Figure 10ENSO surf zone morphology at Terrigal-Wamberal. Cumulative bed level change $>$ one standard deviation, $\sigma$, around the mean, $\bar{x}$, is shown in $0.5 \sigma$ increments, where $\sigma$ and $\bar{x}$ are given for each case. Wave roses show offshore directional wave power density. White line shows seaward limit of upper shoreface (15 $\mathrm{m}$ isobar), black circles show nearshore wave output points(Figures S6 - S7), and boxes show locations of erosion hotspots. 
Vectorsin a) indicate time-averaged sand transport direction over the simulation period for all cases. Red boxes highlight morphology with greatest seasonal difference.

Figure 11Idealized model of surf zone change during a summer-to-summer El Niño/La Niña cycle for EP and CP ENSO climate. Arrows represent wave direction; green (white) arrows indicate direction of (sub) dominant modal wave power (cumulative for season); red arrows indicate mean storm wave direction during La Niña winter. Areas of accretion are shown in orange with the outline of the preceding season's pattern below. Plots also show location of diffraction point, wave obliquity, $\beta$, and control line length, $R_{\beta}$ according to change in surf zone morphology from TBR / LLT to RBB. $R_{\beta}$ is given relative to compartment length, $L$. 

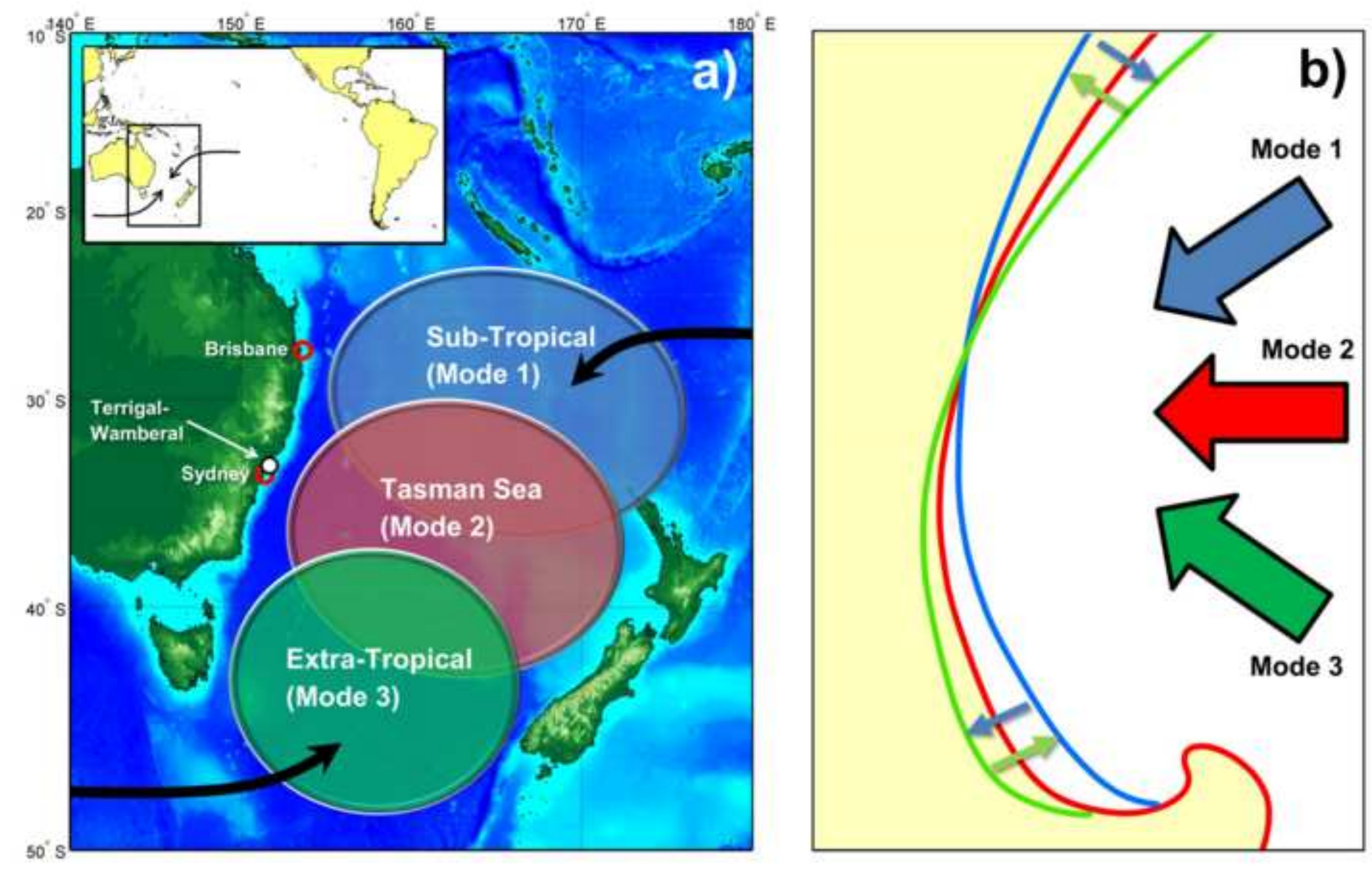

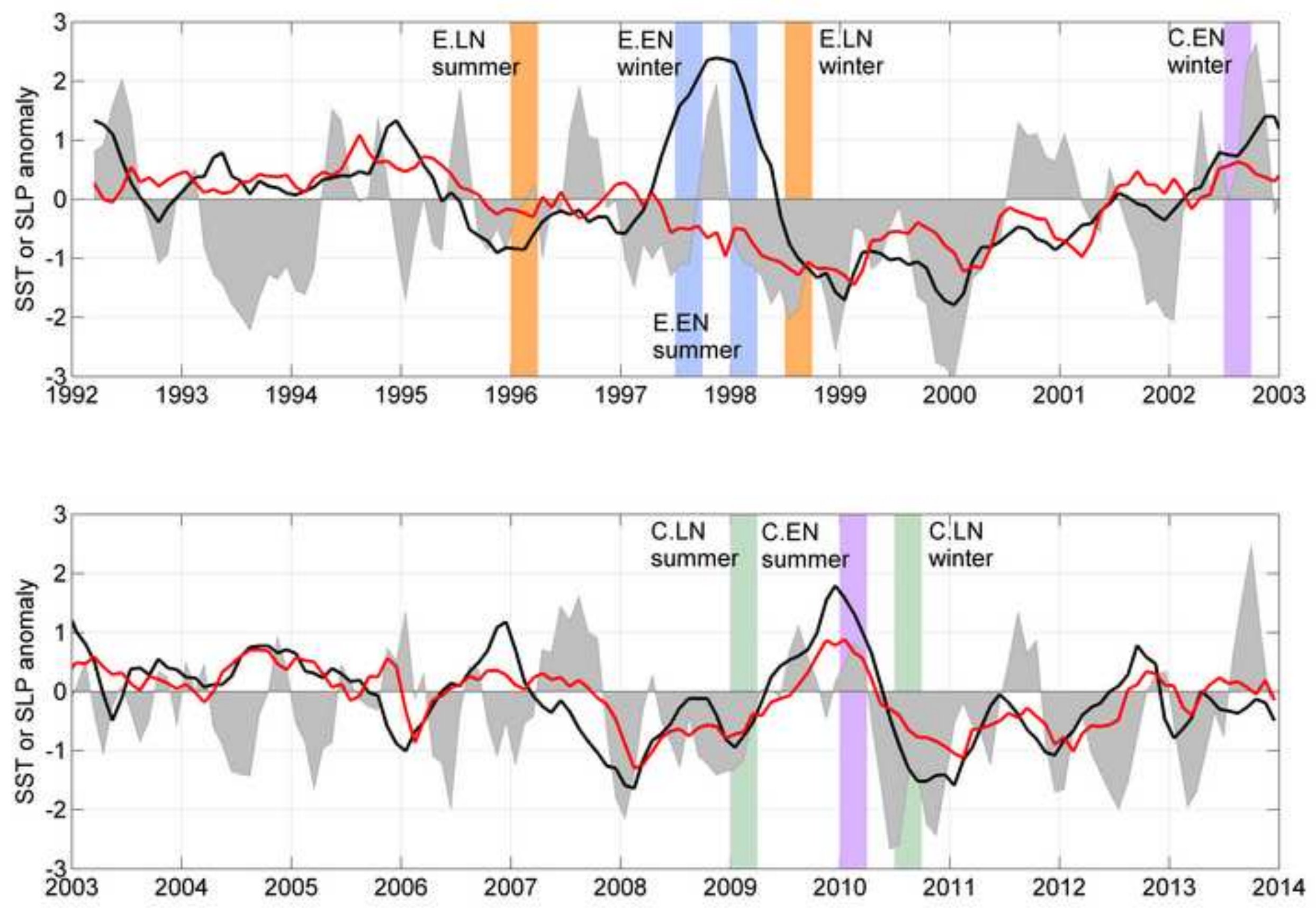
a)

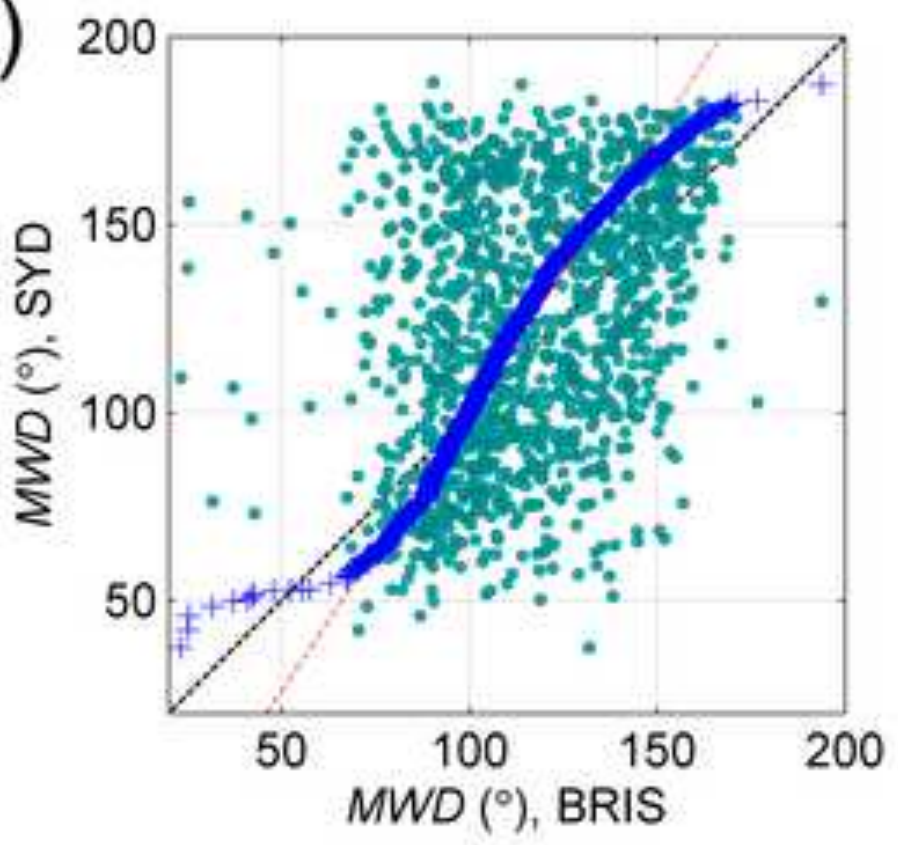

c)

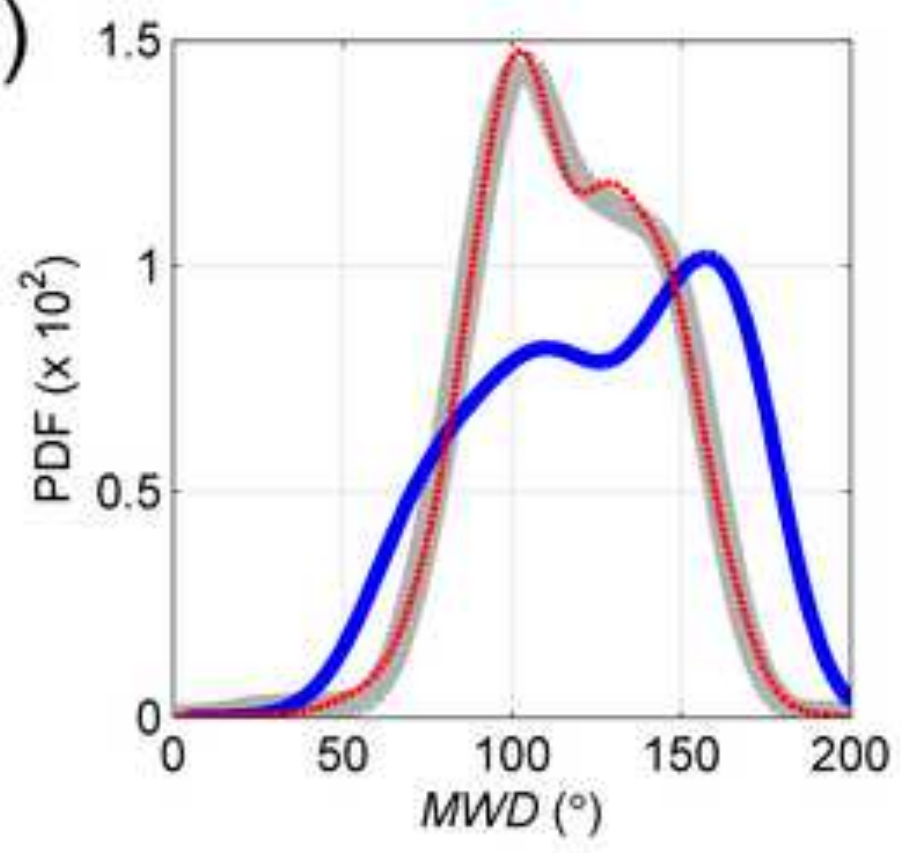

b)

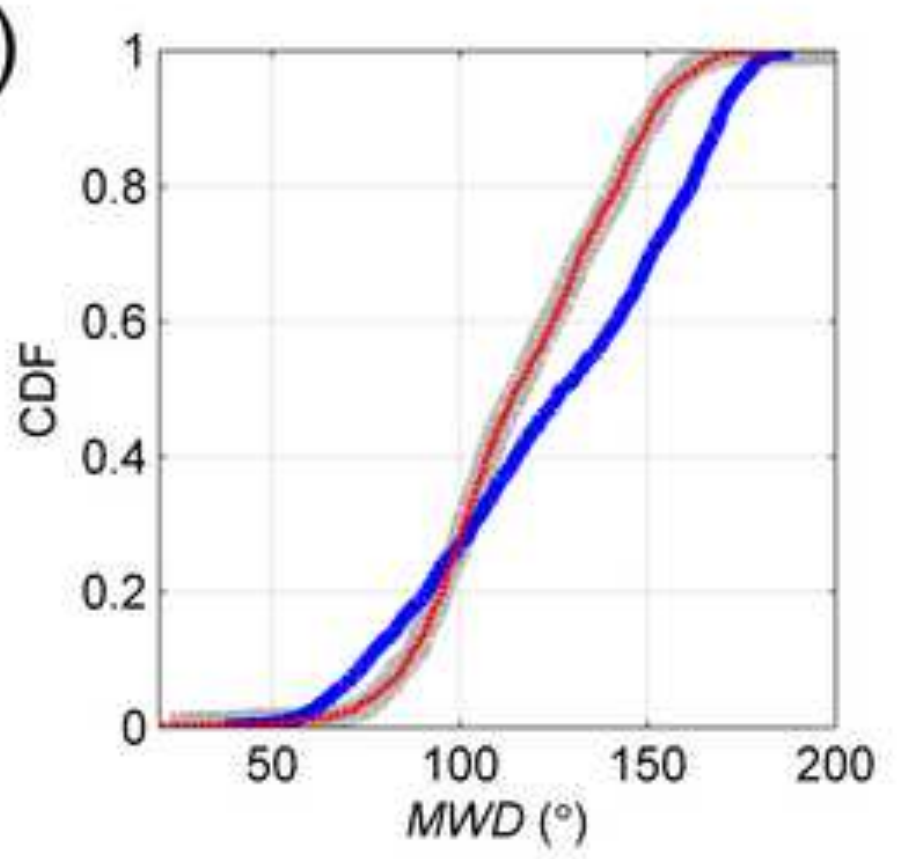

d)

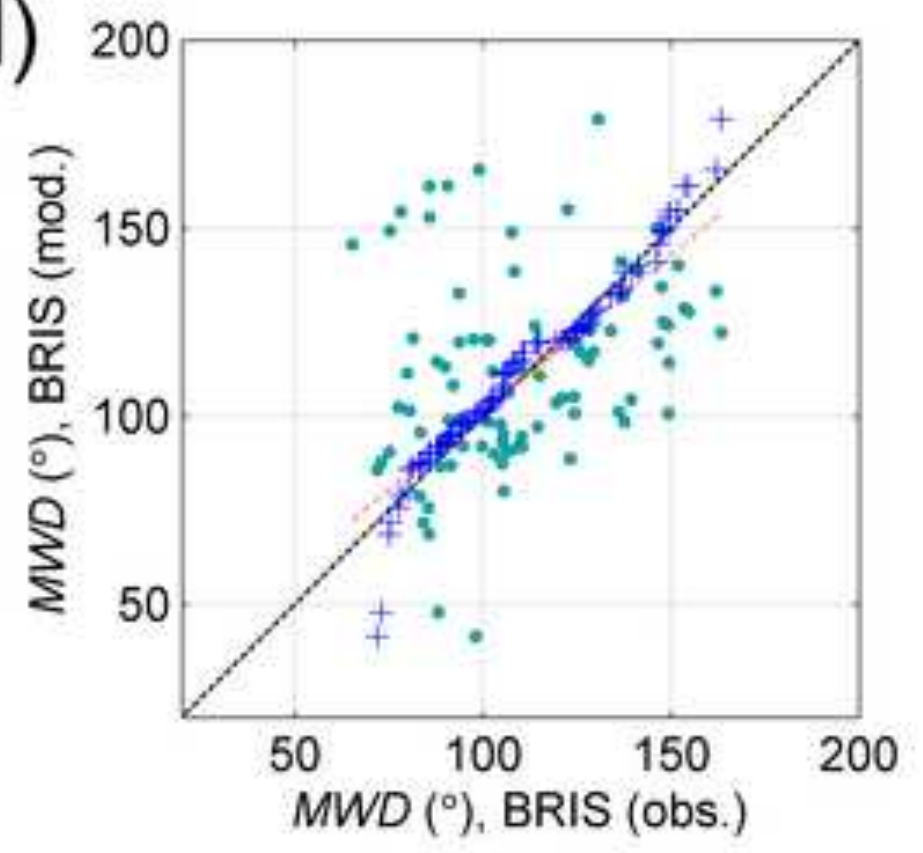


Mode 1a (NE)

North-Easterly Trade Winds

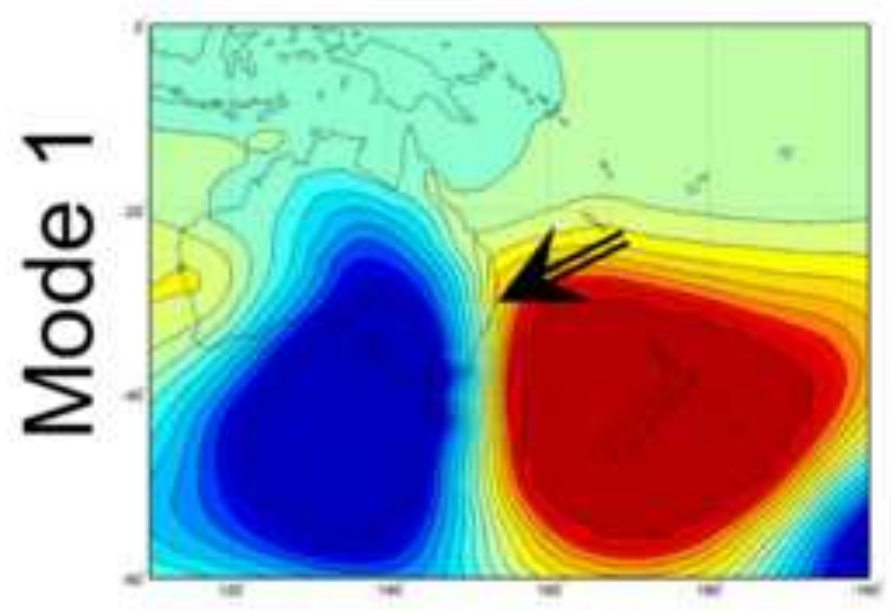

Mode 2a (ESE)

Southern Tasman Anticyclone

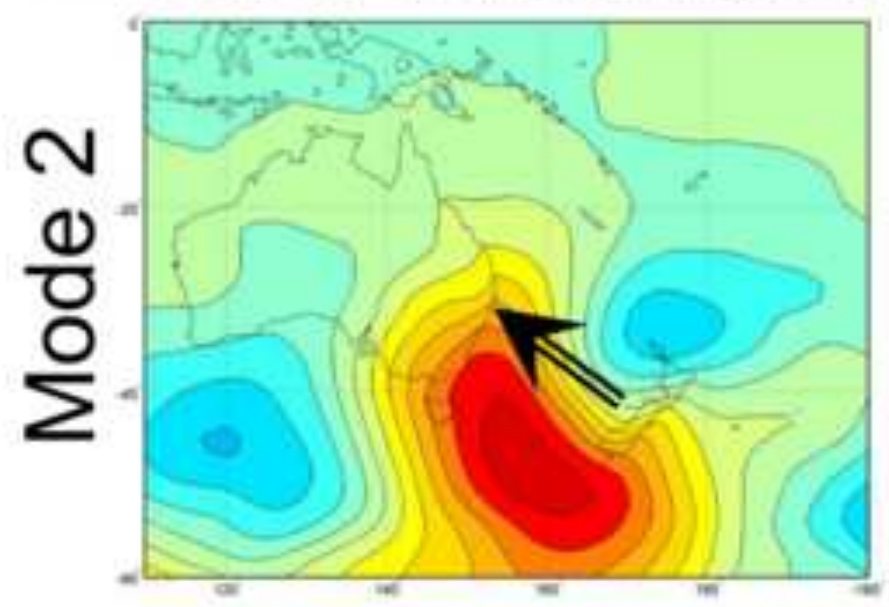

Mode 3a (SSE)

Southern Ocean Low

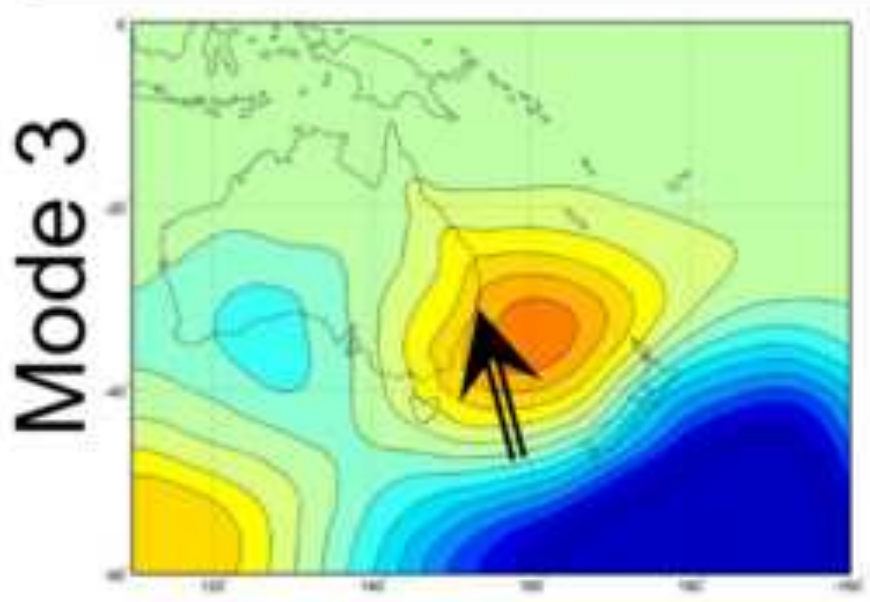

Mode 1b (E)

Zonal Easterly Trade Winds

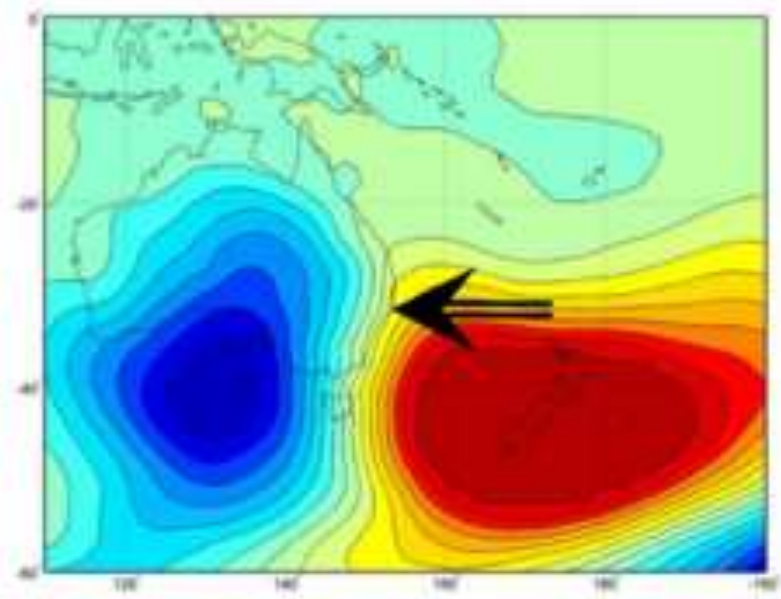

Mode 2b (SE)

Central Tasman Low

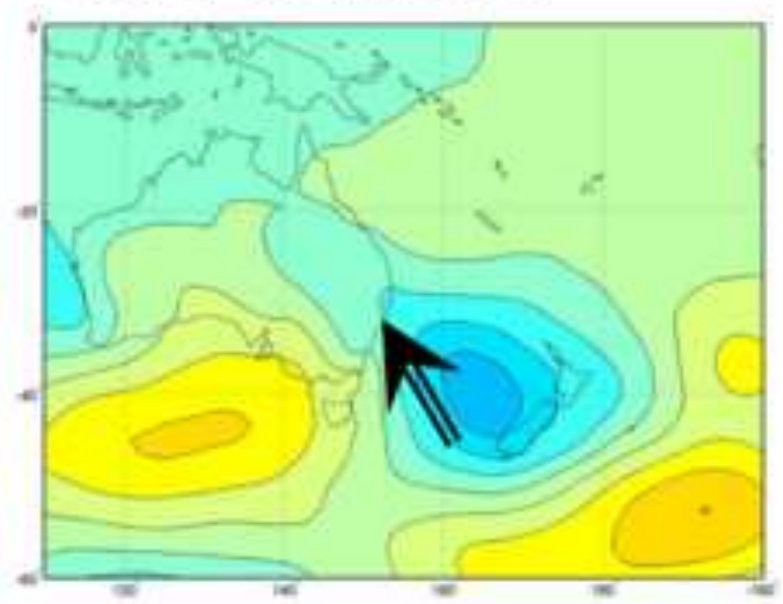

Mode $3 b$ (SSE to S) Southern Tasman Low

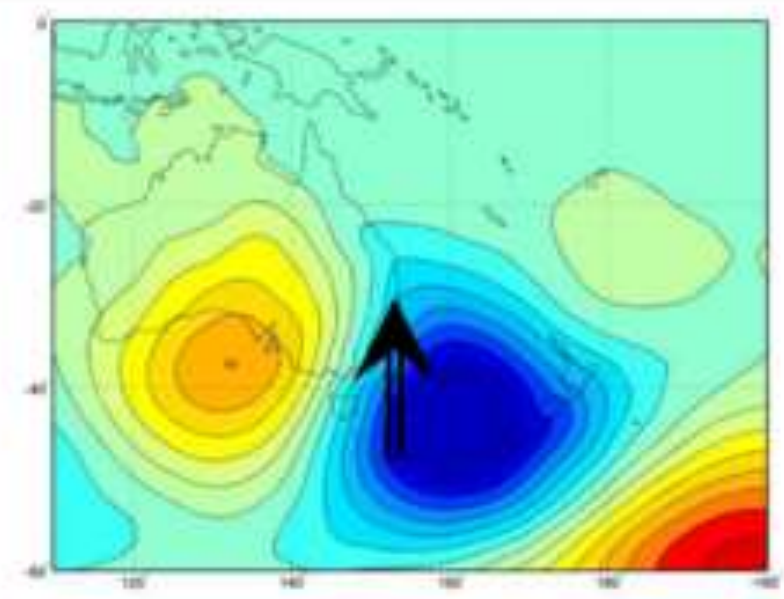

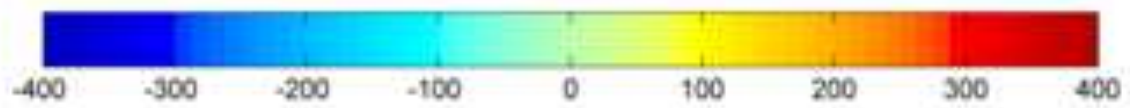




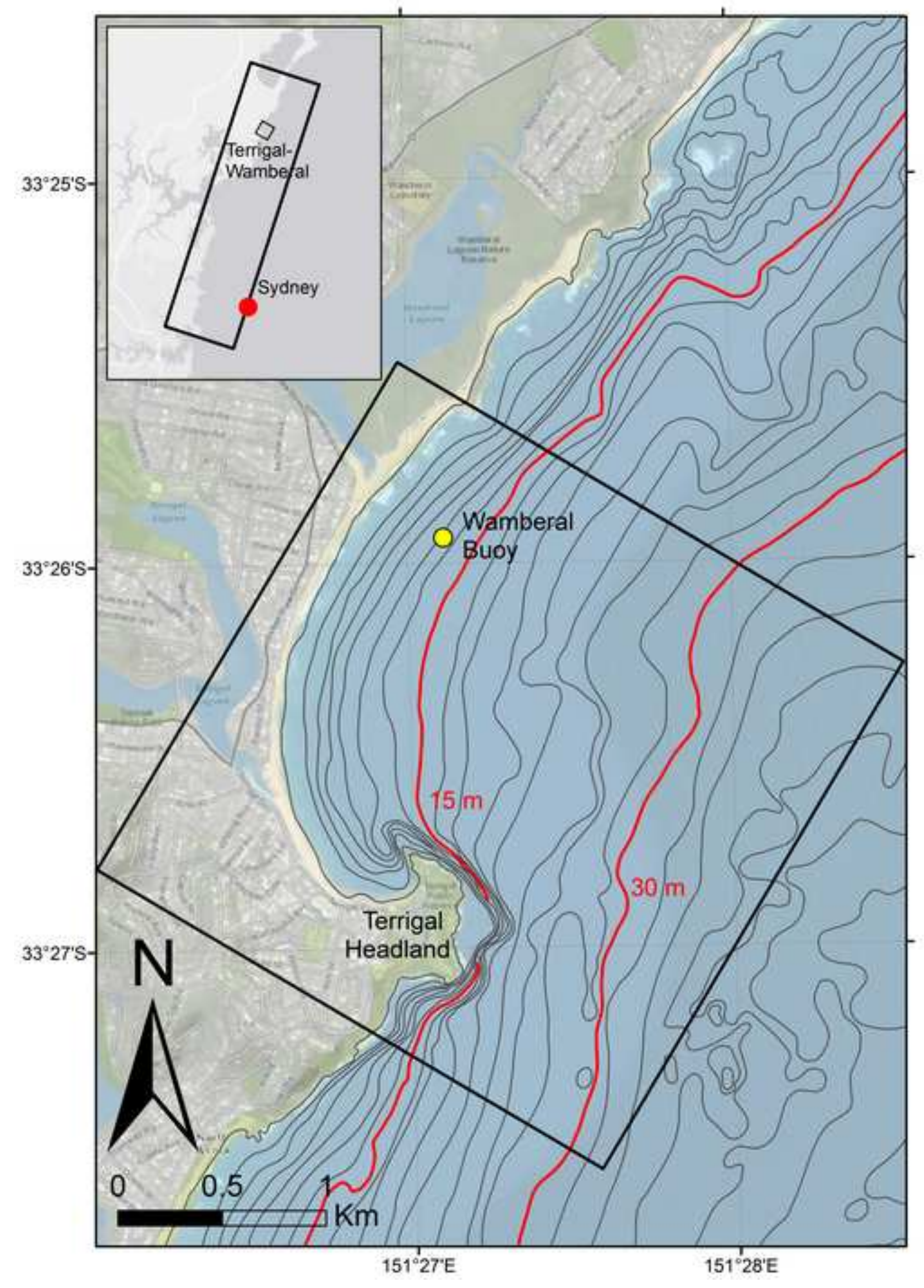

Figure 5

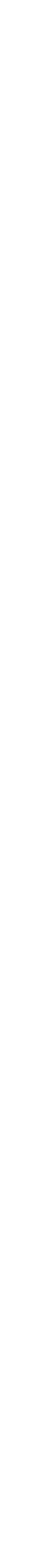



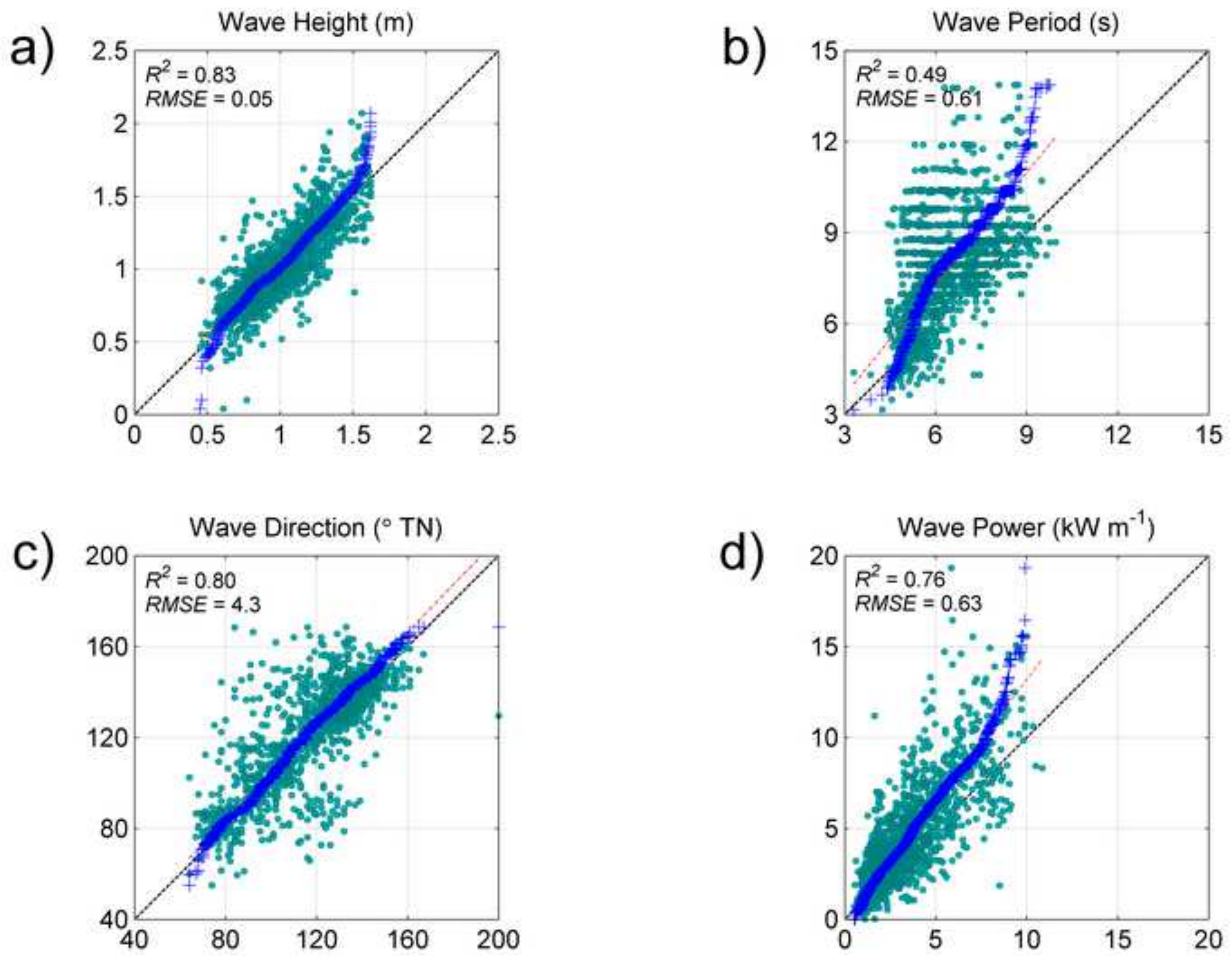
EP EI Niño Summer
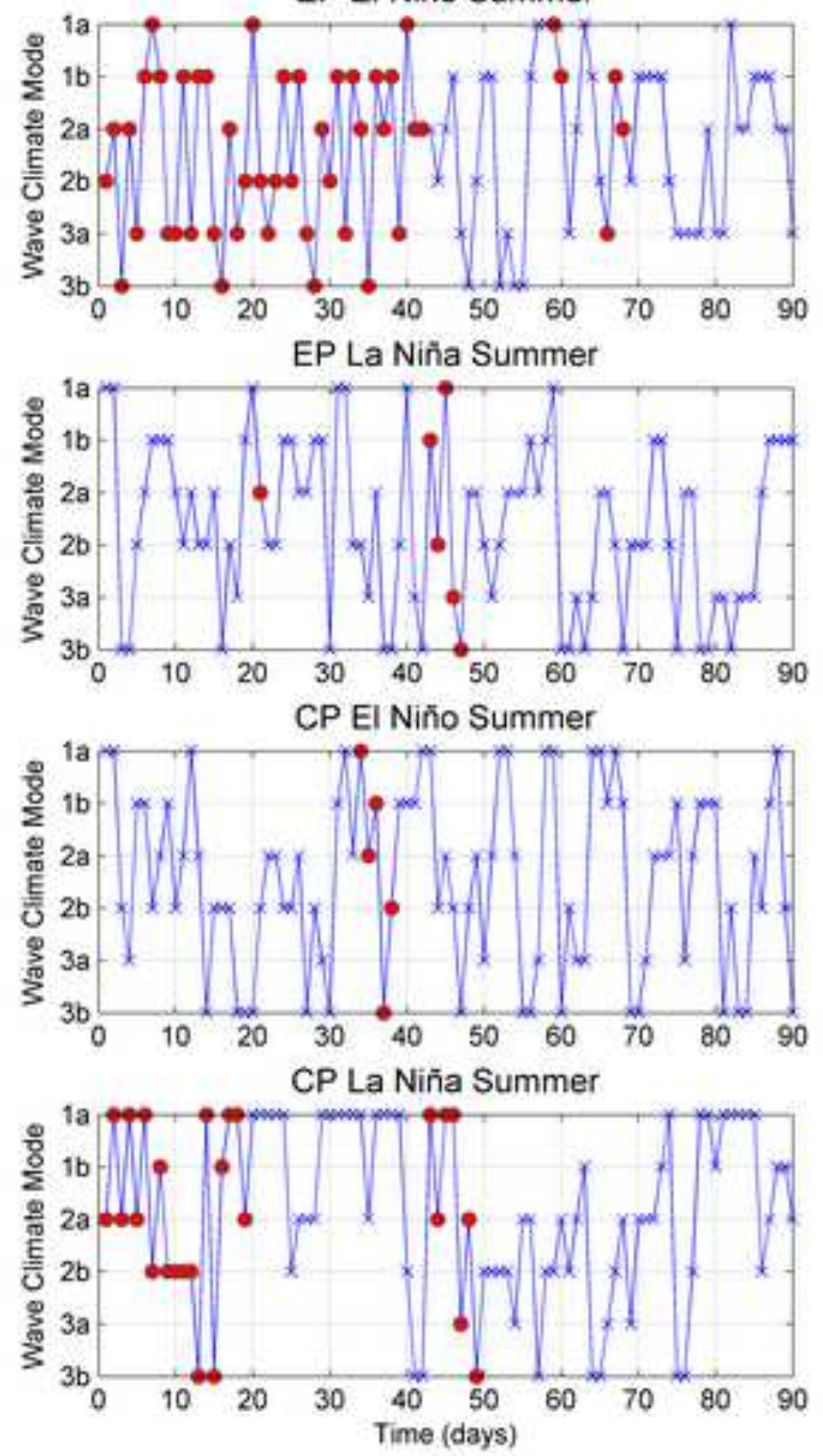

EP EI Niño Winter
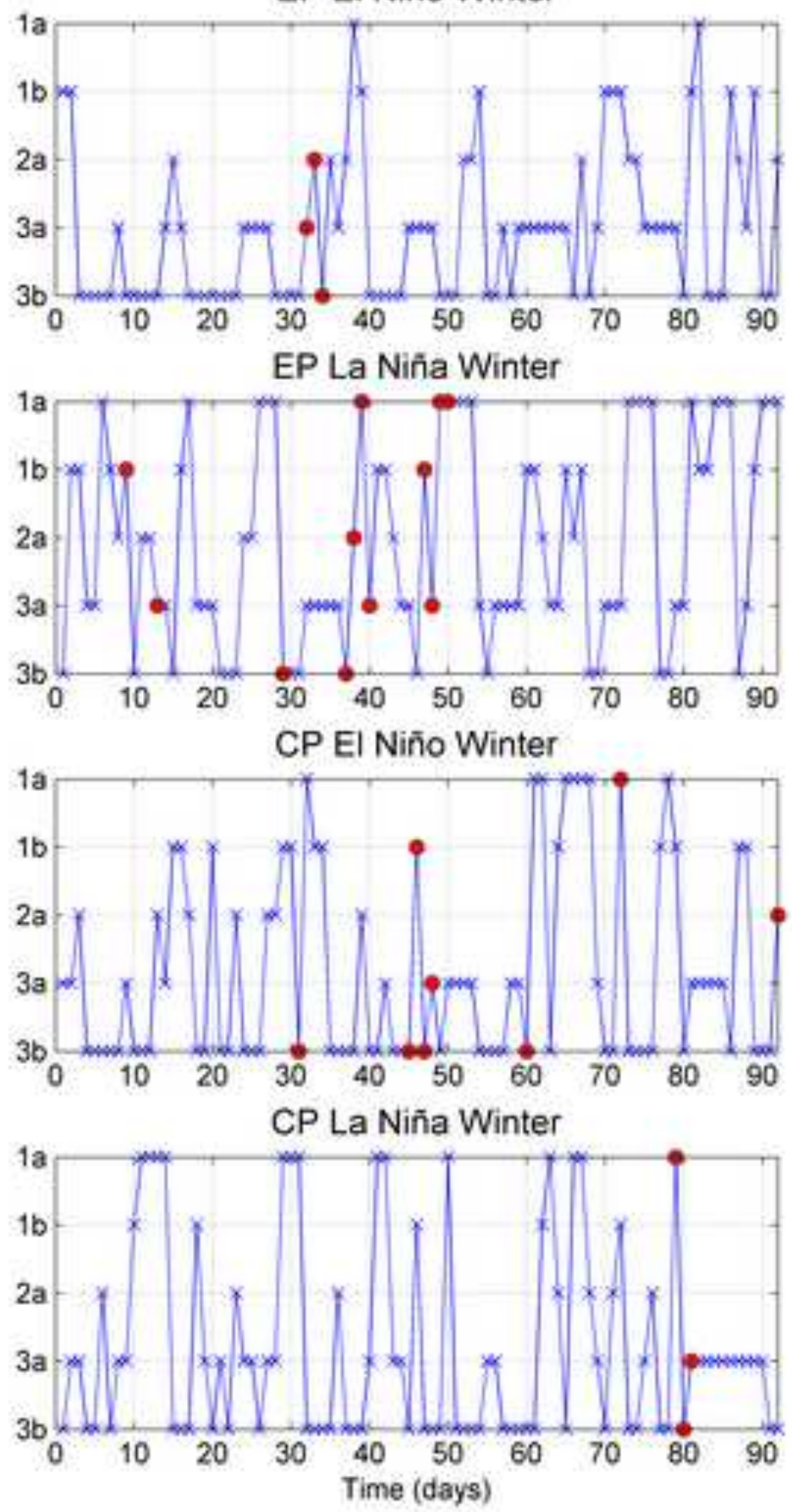
ENSO Directional Wave Power at Sydney $\left(33.8^{\circ} \mathrm{S}\right)$

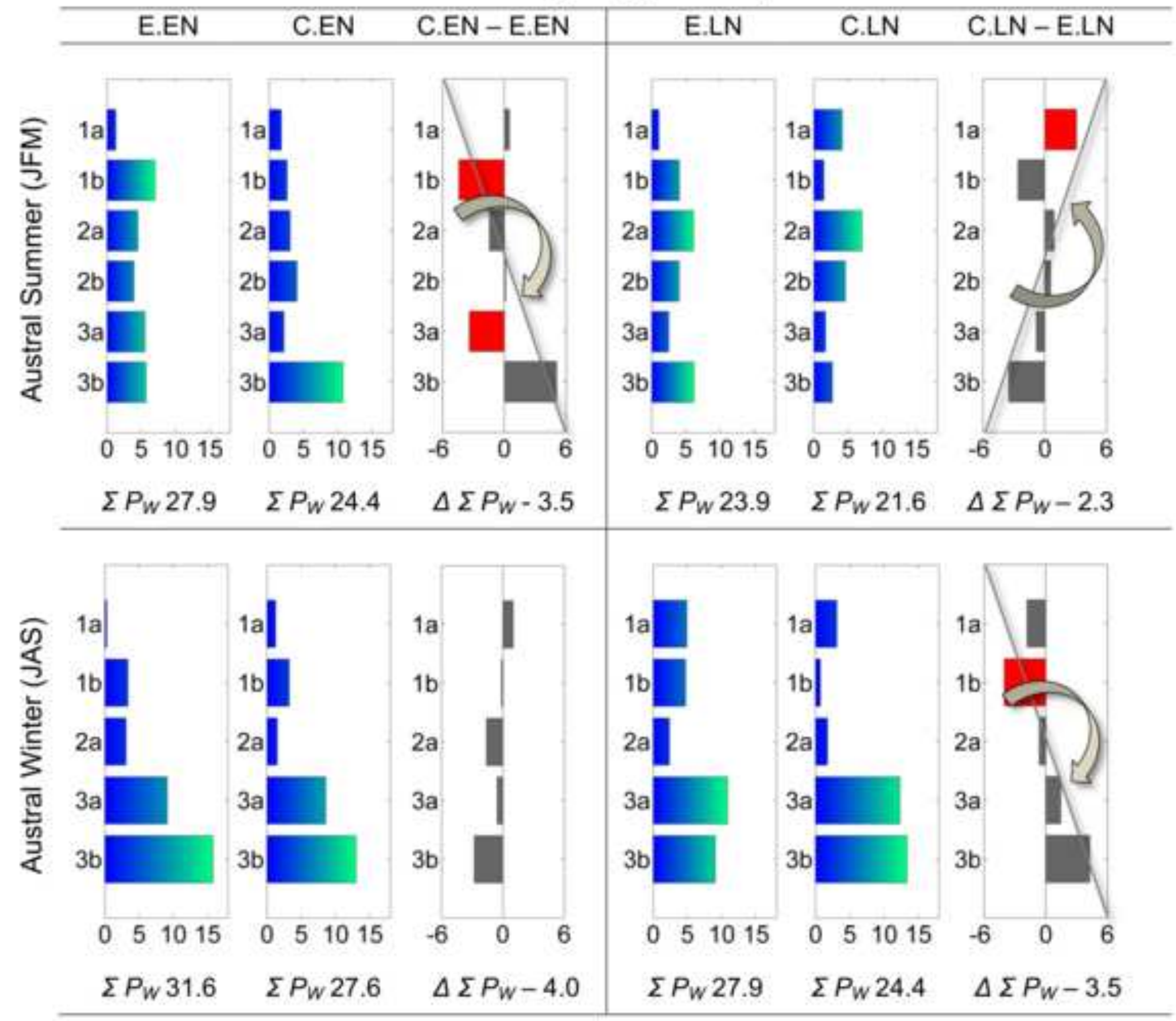


ENSO Directional Wave Power at Brisbane $\left(27.5^{\circ} \mathrm{S}\right)$

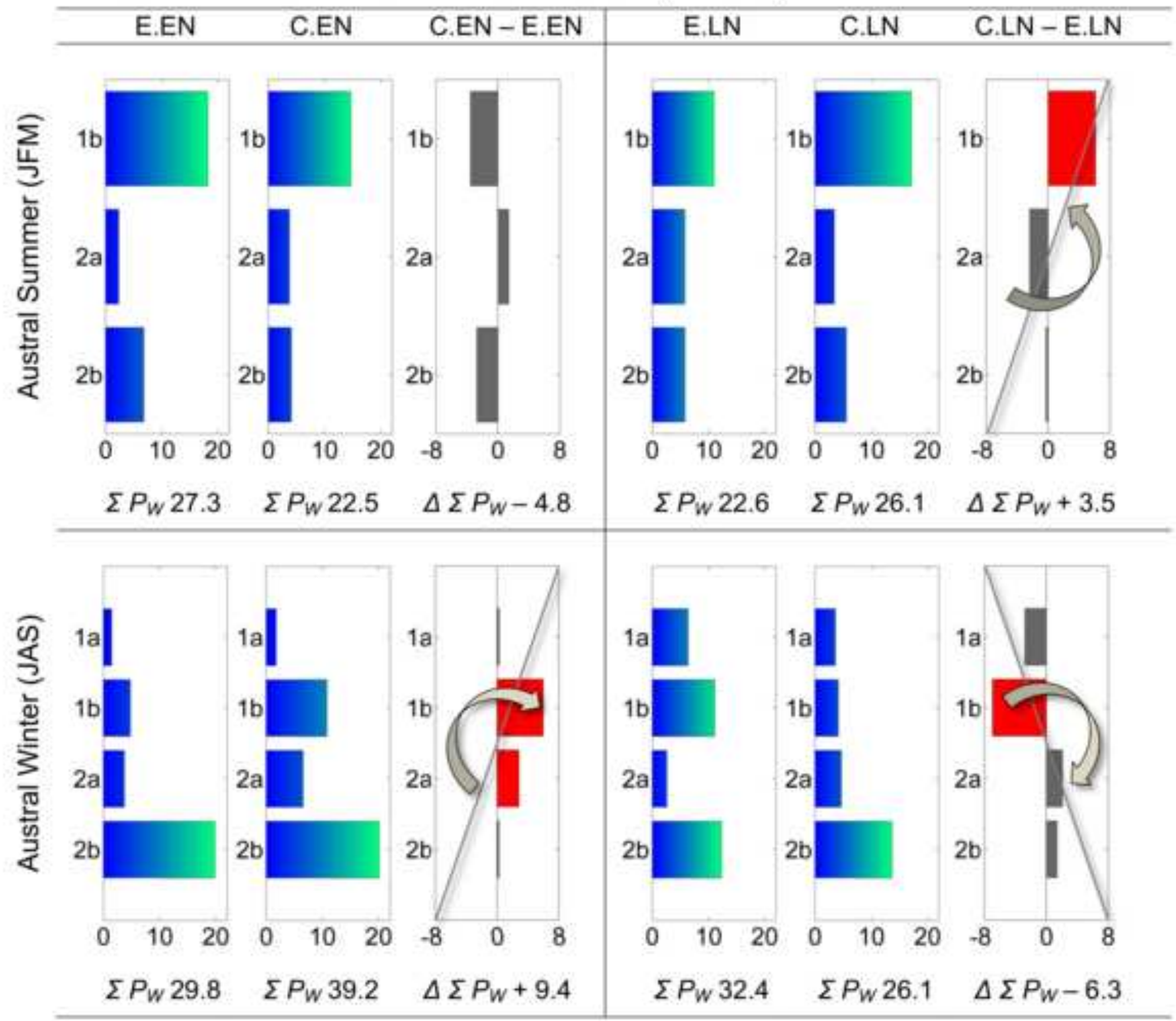



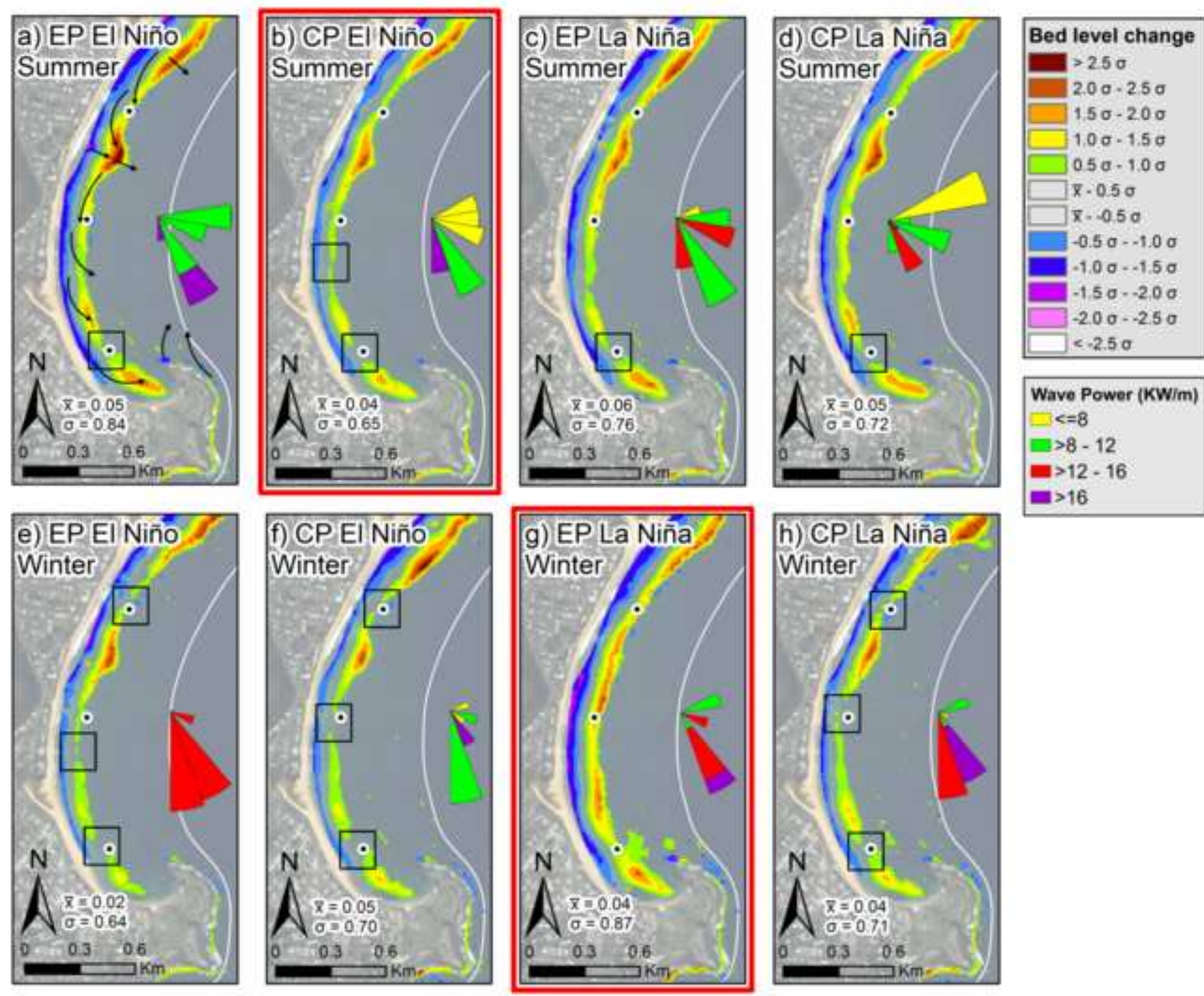

\begin{tabular}{|c|}
\hline \multirow{2}{*}{$\begin{array}{l}\text { Wave Power (KWim) } \\
\qquad=8\end{array}$} \\
\hline \\
\hline$\geq>8-12$ \\
\hline$=>12-16$ \\
\hline$=>16$ \\
\hline
\end{tabular}


Eastern Pacific ENSO
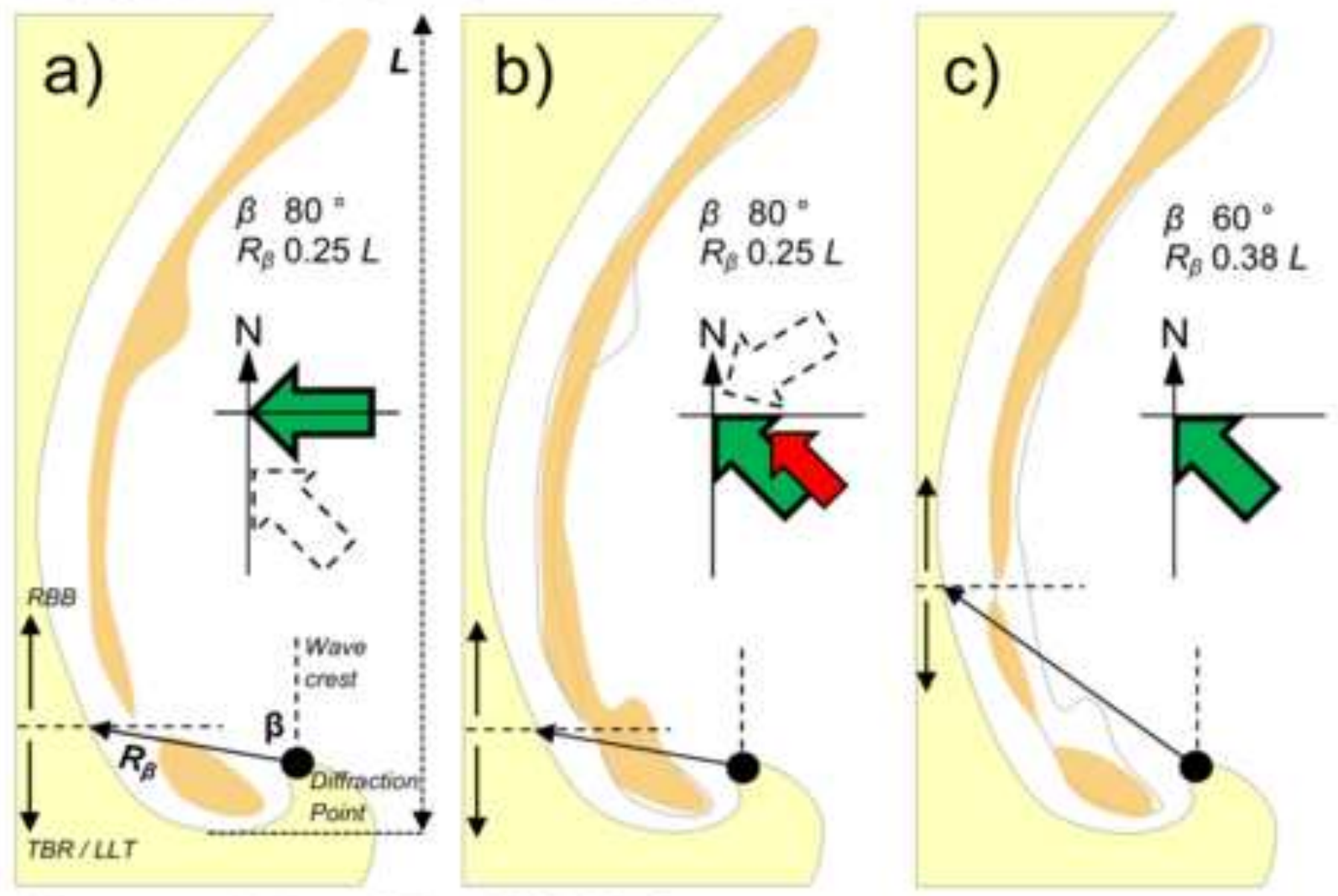

\section{Central Pacific ENSO}
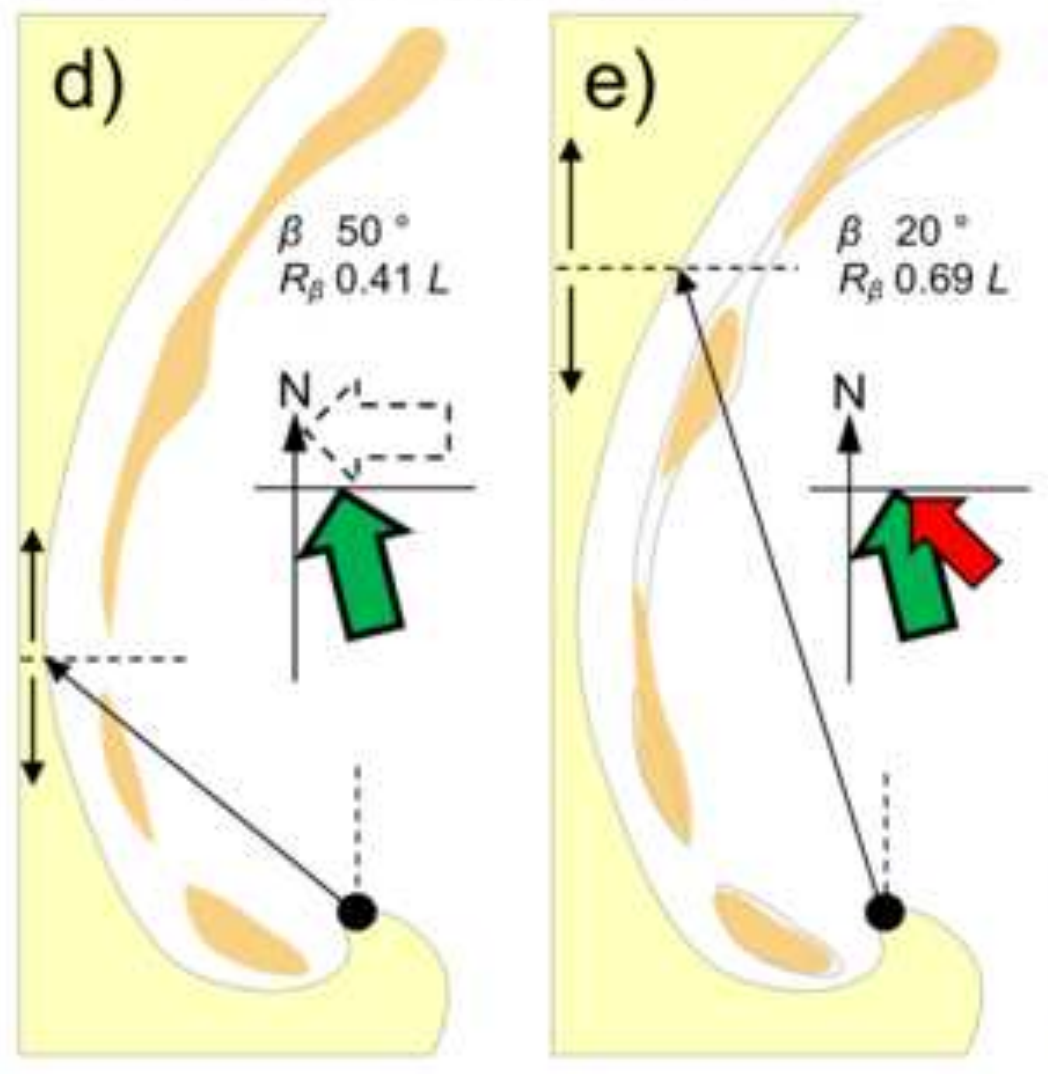

f)

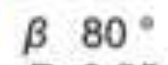

$R_{B} 0.25 \mathrm{~L}$
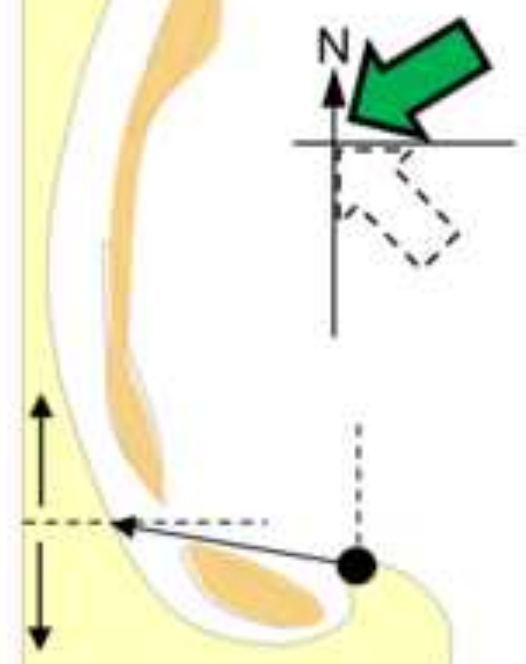

La Niña Summer 